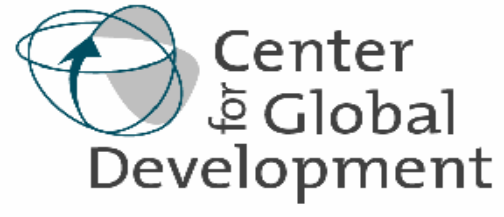

Center ò Global Development
Working Paper Number 93

August 2006

Development, Democracy, and Mass Killings

By William Easterly

The Center for Global Development is an independent think tank that works to reduce global poverty and inequality through rigorous research and active engagement with the policy community. This Working Paper was made possible in part by funding from the William and Flora Hewlett Foundation.

Use and dissemination of this Working Paper is encouraged, however reproduced copies may not be used for commercial purposes. Further usage is permitted under the terms of the Creative Commons License. The views expressed in this paper are those of the author and should not be attributed to the directors or funders of the Center for Global Development.

www.cgdev.org 


\title{
Development, Democracy, and Mass Killings
}

\author{
William Easterly \\ New York University, Center for Global Development \\ Roberta Gatti \\ Development Research Group, World Bank, CEPR
}

Sergio Kurlat

Development Research Group, World Bank

\footnotetext{
*The views expressed here are those of the authors and not of the World Bank or its member countries. We thank the editor, two anonymous referees, and participants to the Annual Political Science Association meetings for useful comments. We are grateful to Hairong Hu for heroic research assistance and data collection. Address correspondence to:

William.easterly@nyu.edu.
} 
When human lives are endangered, when human dignity is in jeopardy, national borders and sensitivities become irrelevant. Whenever men or women are persecuted because of their race, religion, or political views, that place must - at that moment - become the center of the universe.

Elie Wiesel

\section{Introduction}

The $20^{\text {th }}$ century closed with many lamenting civilian killings by the state (including genocide) as its greatest evil. By one estimate, governments killed as many as 170 million civilians from 1900 to 1987 - more than all the soldiers killed in the wars of the $20^{\text {th }}$ century. ${ }^{1}$ The century closed with a new euphemism for killing and deportation: “ethnic cleansing.” Massacres in the Balkans and the 1994 Rwandan genocide led to much ex post agonizing about what international policymakers could do to prevent or stop mass killings of civilians The new millennium has already featured killings of people whose sole fault is their membership in a group defined by the killers. Killing innocent people, even when the numbers are small relative to population, leaves indelible human scars in the affected groups and a lasting mark on subsequent politics.

Even granting that it is a great evil, however, why should development economists study mass killings when a vast literature by political scientists and other researchers already exists (see references in Charny,1999, as well as our own bibliography)? The first reason is the broader definition of development increasingly adopted by many academics and development practitioners, which includes many aspects of well-being besides just measuring GDP. Freedom from the risk of being killed by the state, and freedom from having your "group" being the target of violence, is surely an important component of social well-being. The second is that political violence has major consequences for economic development even in the narrow sense, sometimes with 
decades of development efforts undone by outbreaks of violence. The third is that the likelihood of political violence may depend on economic incentives and behaviors. Due to such considerations, political violence (especially civil war) has recently become a major subject for research among economists. ${ }^{2}$

Due in part to the recent literature on political violence, violence (and its corollary, the breakdown of state authority or "state failure") has become something that international development policy makers like the World Bank, United Nations, or OECD seek to address. Altogether, five different articles in Foreign Affairs in the past few years have analyzed what international policy makers could do about failed states. ${ }^{3}$ In a recent report, the World Bank made the claim "Our new understanding of the causes and consequences of civil wars provides a compelling basis for international action. ... International action ... could avert untold suffering, spur poverty reduction, and help to protect people around the world from ... drug-trafficking, disease, and terrorism." ${ }^{4}$

Although we are cautious in thinking that economic research can develop a comprehensive understanding of such a complex problem, we share the interest of the economics of violence literature in understanding the determinants of the many forms of political violence. This paper represents an important extension of that literature, as the phenomenon of mass killing has received little attention so far in the literature by

\footnotetext{
${ }^{1}$ Rummel (1997).

${ }^{2}$ Some references from the large literature by economists includes Collier (1999), Collier and Hoeffler (1998, 2002a, 2002b, and 2004), Azam and Hoeffler (2002), Stewart et al. (2001), and Reynal-Querol (2002a and 2002b). See World Bank (2003) for a more comprehensive list of references.

${ }^{3}$ Sebastian Mallaby, "The Reluctant Imperialist: Terrorism, Failed States, the Case for American Empire," Foreign Affairs (March/April 2002); Chester Crocker, "Engaging Failing States,” Foreign Affairs, (September/October 2003); Stuart Eizenstat, John Edward Porter, and Jeremy Weinstein, "Rebuilding Weak States,” Foreign Affairs (January/February 2005), Stephen D. Krasner and Carlos Pascual, “Addressing State Failure,” Foreign Affairs (July/August 2005), Stephen Ellis, "How to Rebuild Africa" Foreign Affairs (September/October 2005).

${ }^{4}$ World Bank (2003) p.168.
} 
economists. Like civil war, mass killings seem a priori likely to have huge economic consequences, and to possibly be influenced by economic factors. More over, mass killings are one of the main components of definitions of "state failure."

Economic development is potentially a two-edged sword for mass killings of civilians by the state. On the one hand, economic development leads to increased education that might promote greater tolerance of other groups besides one's own. From a more cold-hearted calculation, economic development is an increase in the productivity of labor and hence the value of human life. On the other hand, economic development brings advances in technology and social organization that lower the cost of mass killings. Murderous political leaders can use advanced technology and social organization to kill.

One factor that might resolve the ambiguity between development and massacres is institutions. Good institutions will presumably increase the likelihood that technology and organization are used for benevolent ends. The most obvious institution that has been developed to ensure benevolent governments is democracy, which places limits on the ability of the executive to carry out destructive acts against the electorate. Indeed, one of the most famous hypotheses about genocide is that "power kills; absolute power kills absolutely" (Rummel, 1997).

However, again there is some ambiguity about the relationship between democracy and episodes of massacre and genocide. A majority of the population may democratically agree on the killing of an unpopular minority. Famous historical examples are the democratic governments in Australia, Canada, and the United States 
who killed indigenous peoples. So it is still an open empirical question about whether democracy successfully turns economic development towards benevolent ends.

These are the questions that motivate our study.

The contribution of this paper is twofold. First, using historical records and sources, we compile a new dataset listing occurrence and cruelty of episodes of mass killing by the state over the XIXth and XXth century. We then couple this information with historical series on the extent of democracy and on GDP and conduct a systematic analysis - to our knowledge the first of its kind - of the relationship among these variables.

The paper is structured as follows. Section II discusses the definitions of our main variables and section III describes data sources and summary statistics. Sections IV and V discuss regression results and robustness checks. Section VI concludes.

\section{Defining mass killing episodes}

In the process of identifying episodes of mass killings of civilians by the state one has to confront the question of defining genocide. There are many contentious issues in this field. First, a number of scholars - especially in the past - have disputed whether comparative analysis of genocide is at all meaningful, given the unique characteristics of each episode, however genocide is defined. Nonetheless, more and more scholars have recently advocated the use of comparative research on genocide as an instrument to understand which underlying conditions are more likely to put a polity at risk. In the words of Barbara Harff, one of the most prominent scholars in the current literature, "All cases have unique properties but also share some discernible patterns with others, from 
which social scientists can identify some common sequences and outcomes” (Harff, 1992, p. 30).

Although in 1948 the United Nations adopted an official definition of genocide, scholars are far from agreeing on how genocide should be defined, often arguing over narrow versus more inclusive definitions. A narrow definition, for example, is that genocide must involve the intention to exterminate an ethnic group. There are very few such episodes, with scholars usually referring to the Nazi Holocaust of the Jews and, more recently, the Hutu killings of Tutsis in Rwanda. This definition would leave out mass killings of political victims, such as those in Cambodia, China, and the USSR. In the view of many scholars, massacres of political victims should also be including in a more comprehensive definition of genocide (see, for example, Harff, 1987, who focuses, amongst others, on politicides - i.e. genocides, where victims are defined primarily in terms of their political opposition to the regime and dominant group; and Horowitz, 1997). According to others, instead, the clear intent to eliminate a group (where a group and membership in it are defined by the perpetrator and not by external fixed criteria) is the relevant element that distinguishes a genocide from other gross human rights violations (Chalk and Jonasshon, 1987).

A complementary approach is that of classifying genocides based on the motives of the perpetrators, whether these were desire for revenge - as it was typical of ancient times (examples are the massacres perpetuated by Genghis Khan); an accessory to military conquest, as it was often the case in the middles ages; or a means to monopolize power or to impose an ideology (Smith, 1987). 
Within this debate, there are a few elements of general convergence. For example, authors uniformly stress the disparity of power between perpetrators and the victim group as a typical characteristic of genocide and tend to exclude victims of warfare and bombings.

In this work, we define episodes of mass killings following the highly inclusive definition of Charny (1999, p. 7):

Genocide ... is the mass killing of substantial numbers of human beings, when not in the course of military action against the military forces of an avowed enemy, under conditions of the essential defenselessness and helplessness of the victims.

The word genocide has become politically explosive, with states threatening reprisals against other states that publicly identify a historical episode as a "genocide". Other political activists have watered down the definition to label almost any government policy (abortion, economic sanctions, monetary policy) as "genocide" against some group. A search on the word "genocide" on Yahoo turned up 141,000 web pages.

To stay out of politics while at the same time communicating clearly, we adopt the following compromise. Throughout the paper we refer to episodes interchangeably as "mass killings" or "massacres". We do not intend this wording to be a euphemism for "genocide," since we not believe that all episodes in our sample were genocides. We simply avoid the loaded word "genocide" altogether. We adopt the broad definition advocated by Charny in the paragraph above for "mass killings." In most cases, the state is either actively or passively involved in the killings, although there are some borderline cases where we cannot distinguish between people killed by state forces versus other armed forces. ${ }^{5}$ Note that we do not identify episodes ourselves, but we include in our

\footnotetext{
${ }^{5}$ In particular, we do not include in our definition victims from international wars.
} 
sample episodes that have been identified as mass killings over the past two centuries by other academic researchers. The standard generally followed by these researchers is compatible with Charny's definition.

We choose the last two centuries because that is the period over which democracy and income data are available. In this sample, we counted a total of 163 episodes of mass killings in 71 countries.

A research assistant and one of the coauthors, who did not hold any priors with respect to the relationship among development, democracy, and mass killings, performed the literature search. Given limited resources to search the literature, we cannot argue that our list is exhaustive. We could hope that such errors of inclusion and exclusion are random, so that we can still estimate unbiased coefficients on the variables of interest, development and democracy.

Unfortunately, there is likely to still be some association between probability of inclusion in the sample and our right-hand side variables. Societies that are more democratic, and thus have freedom of speech and press, are more likely to record any episodes of mass killings, while authoritarian societies may keep mass killings a secret from the history books. This is likely to generate a selection bias against mass killings that occur in less democratic societies.

In addition, societies at a lower level of income are less likely to have information on the democracy level of their regime, or they are a colony of another nation and so are not counted in the democracy sample. Low income also makes it more likely that income itself will not be recorded. Hence our sample that includes observations on mass killings, 
development, and democracy is likely to under-represent low-income societies. However, these problems are common to similar cross-country studies.

\section{Data description}

Our income data are drawn from different sources. For the $19^{\text {th }}$ century, Maddison estimates income in 1820, 1850, and 1870, and then yearly after 1870 . This procedure might be thought to under-represent the middle-income experience of today’s industrial countries, which took place mainly between 1820 and 1870 . We know with some degree of approximation that income was in the middle-income range in the intervening years if it was in the middle-income range in both 1820 and 1850, and likewise with 1850 to 1870. In order to maximize the size of our sample and, in particular, to obtain sufficient data for the XIXth century, we interpolate income linearly from 1820 to 1850 and from 1850 to 1870 . Income data for the period 1950-1990 is drawn from Summers and Heston and is updated and filled in with World Bank National Accounts per capita growth rates up through 1998.

Measuring democracy is more problematic as there are many angles to its definition. For example, democracy can be measured as a continuum representing the degree to which coercive regime power penetrates and controls political and socioeconomic institutions; as the degree of effective political competition; or as the degree of concentration and centralization of political power (Rummel, 1997). Although there exist in the literature a number of indicators that are meant to capture the different dimensions of democracy, none of them is available for the period that our data span. To be able to analyze our full data set, we use a democracy variable from the well-known Polity III 
project at the University of Maryland that covers an exceptionally long period: 18001998. This variable captures important procedural elements of democratic institutions. ${ }^{6}$ In particular, it measures the degree of openness of the political process by ranking regimes according to the competitiveness of participation to political life (i.e. the extent to which non-elites are able to access institutional structures for political expression); the type of competition for executive recruitment (i.e. the extent to which executives are chosen through competitive elections); the openness of the executive recruitment (i.e. the opportunity for non-elites to attain executive office); and, finally, the degree of constraints on the executive (i.e. the operational independence of chief executive). The index is measured on a scale from 0 to 10 . Its construction is described in detail in Appendix I. Mass killings episodes are listed and described in Appendix II.

\section{Descriptive analysis}

We first present some descriptive analysis of the association between development, democracy, and mass killings. In the following sections, we will discuss formal econometric analysis of the data.

Our data are characterized by infrequent mass killing episodes taking place over the period 1820-1995 and by strings of missing values in the income data, especially as far as the XIXth and the beginning of the XXth century are concerned. The peculiar structure of the data makes the choice of how to setup the timing of the regressions whether in a single cross-section, by century, decades or year - particularly relevant. Arranging the data by decades allows us to strike a reasonable balance between being

\footnotetext{
${ }^{6}$ We should also note that some definitions of democracy (a regime could be defined democratic if it does not commit massacres, genocides, etc) would be tautological in the context of this paper (Jonasson, 1990).
} 
able to link episodes of mass killings to income levels relatively close in time and avoiding a misleading multiplication of observations that would occur, for example, with annual data.

To identify massacres we use a dummy for those years and countries in which a mass killing episodes occurred. In our setup, this amounts to having an indicator variable taking value of 1 if a massacre occurred in the decade. In this sense, this dummy measures the frequency of mass killings but not their magnitude, as it does not use information on the number of victims. We then present data on the estimated numbers of victims associated with each episode. These estimates are usually given in the original bibliography as a range of estimated victims, and we take the mean of the minimum and maximum of the available estimates.

To summarize the interrelationships among democracy, development, and mass killings, we segment the sample of more than 1000 observations into quartiles of income per capita and democracy. Cutoffs for income quartiles are at \$908, \$1671 and \$3619 in 1985 dollars. The low quartile of democracy is at zero, while the other cutoffs are at 3 and 8.78. Figures 1-4 show the frequency and number of mass killings in the different quartiles of development and democracy.

A simple correlation between massacre frequency and per capita income over the whole sample suggests a negative relationship between the two variables (correlation of 0.11). Interestingly, though, the graph of massacre frequency by income quartiles indicate that the unconditional relationship between the two is far from being linear - although massacres appear to be very frequent among the poorest countries and least frequent among the richest countries, they are most frequent in middle income countries (third

Our index does not suffer from this problem. 
quartile, see figure 1). When we split the sample by century, massacres are positively and significantly correlated with income in the XIXth century (correlation of 0.33 ) while they are less likely to occur in richer countries in the XXth century (correlation of -0.18). This is not surprising since most massacres recorded in the XIXth century were in fact perpetrated by imperialist (richer) countries in the context of their colonization policies.

Overall, mass killings are weakly negatively correlated with democracy (correlation of -0.08). The relationship between massacres and democracy is also not linear, with massacre frequency being the highest at intermediate levels of democracy (third quartile) while being the lowest among the countries with the highest level of democracy (see figure 2). Moreover, similarly to what we observe for the massacreincome relationship, massacres were more likely in relatively more democratic countries in the XIXth century, while democracy and mass killings are negatively correlated in the XXth century (correlations of, respectively, 0.42 and -0.16).

Table 1 presents democracy and income quartiles together in a 4 by 4 table. Again, we see some hints of results we will explore further - the relationship with income seems nonlinear, and controlling for income, democracy does not seem to have a straightforward relationship with the likelihood of mass killings. Overall, it is clear that the likelihood of mass killings is lower than in the rest of the sample at the highest quartiles of both democracy and income. 
Table 1: Four by four classification of sample of mass killings by income and democracy quartiles ${ }^{7}$

\begin{tabular}{|c|c|c|c|c|}
\hline \multirow{2}{*}{$\begin{array}{l}\text { Percent of sample } \\
\text { with mass killings } \\
\text { (observations in } \\
\text { each cell in italics) }\end{array}$} & \multicolumn{4}{|c|}{ democracy quartile ( $4=$ most democratic) } \\
\hline & 1 & 2 & 3 & 4 \\
\hline \multirow{8}{*}{ 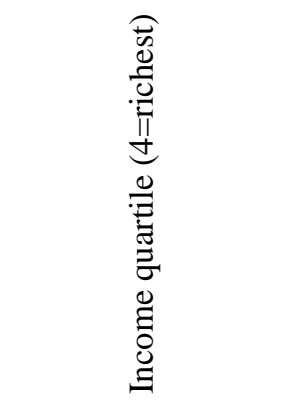 } & $28 \%$ & $24 \%$ & $15 \%$ & $33 \%$ \\
\hline & 105 & 86 & 40 & \\
\hline & $15 \%$ & $13 \%$ & $19 \%$ & $44 \%$ \\
\hline & 71 & 83 & 70 & 9 \\
\hline & $13 \%$ & $25 \%$ & $31 \%$ & $12 \%$ \\
\hline & 48 & 51 & 85 & 50 \\
\hline & $11 \%$ & $11 \%$ & $13 \%$ & $4 \%$ \\
\hline & 36 & 18 & 31 & 148 \\
\hline
\end{tabular}

We next turn to data on the magnitude of mass killings.

Consistently with the setup of our dataset, we measure the magnitude of killings as the average number of victims per decade. Figures 3 and 4 plot the average number of people killed by decade by democracy and income quartiles. ${ }^{8}$ The average number of victims appears to decrease monotonically with income per capita in the whole sample. ${ }^{9}$ Interestingly, the highest average number of victims is not recorded at the lowest level of democracy (totally authoritarian governments) but at intermediate-low levels of democracy (second quartile). A look at sheer magnitudes returns a frightening picture (figure 5): our data suggests that an estimated 70 million people were killed in the past two centuries by non-democratic governments (first and second quartiles of democracy). In general, high democracy appears to be the single most important factor in avoiding large magnitudes of mass killings, as the highest quartile of the sample in democracy

\footnotetext{
${ }^{7}$ Note that, as in the regression setup, these are decade average data. Thus, it only takes one mass killing in a year to identify a whole decade.

${ }^{8}$ The number of victims was assigned to decades as follows. We first calculated the average number of victims per year in each episodes; then we apportioned the average annual number of victims to the decades
} 
accounts for only $0.1 \%$ percent of all the killings. These unconditional associations confirms Rummel's hypothesis that authoritarian power is an important predictor of large-scale killings. The contrast with the conclusions on frequency highlights the fact that killing episodes at high levels of democracy and income involved relatively few victims.

Another noticeable feature of the data is that a small number of episodes accounts for the majority of killings in the data. The five largest episodes - China 1850-73, 192048, and 1949-53, the USSR 1930-38, and Germany 1933-45 - account for 71 percent of all killings, and these episodes involve only three polities. ${ }^{10}$ In order to avoid the obvious problems that this characteristic of the data would create in tobit regressions, we use as dependent variable the logarithm of average killings per decade.

Finally, there were some well-known large-scale killings on which we lack complete data on income or democracy, and are therefore excluded from the data. These are: Cambodia (1975-79); Poland (1945-47); Ex-Yugoslavia (1900-99); Rwanda (1994); Mozambique (1973-75).

\section{Econometric analysis of mass killings}

\section{V.1 What makes mass killings more likely?}

We first analyze the association between the probability that an episode of mass killing occurs and our main variables of interest, the levels of development and democracy of a country. We report estimates in table 2, where the dependent variable

spanned by the mass killing. Because of this convention, information on the intensity of each episode cannot be captured by our data.

${ }^{9}$ Simple correlations suggest that this is the case also in each century.

${ }^{10}$ The USSR 1930-38 episode is split between low and medium development because of rising Soviet income in the 30s. 
takes value of 1 if at least an episode of mass killing occurred during the decade and 0 otherwise. $^{11}$

Due to the length of the time period considered, the number of variables that we can use as regressors is limited. Our main independent variables are average (log) per capita GDP over the decade (LNGDPPC, interpolated when missing) and level of democracy (DEMOCRACY). We also include in all of the regression a dummy for the XXth century to account for possible systematic differences in the occurrence of mass killings in the two centuries, as well as the log of the country's population to control for some basic country characteristics.

Although we experiment with a number of specifications, we should note a priori that teasing out the independent effects of income and democracy on mass killings might not be straightforward, since the correlation between the two variables over the whole sample is quite high (0.55).

One of the widely held tenets about mass killings is that democracy can prevent them (see for example Rummel, 1997, and Chalk and Jonassohn, 1990). We find that, when included alone in the regression, the level of democracy is significantly associated (at the $10 \%$ level) with a lower occurrence of mass killings (column 1). Nonetheless, and quite surprisingly, when we include income per capita in the regression, DEMOCRACY ceases to be significant.

We have seen that the unconditional relationship between frequency of mass killings and democracy is not monotonic. This suggests that it might be helpful to control for democracy in a flexible form. Consistently with the picture in figure 2, when we include indicators for democracy quartiles, mass killings appear to be relatively less

\footnotetext{
${ }^{11}$ Note that, in this setup, an episode spanning two decades is effectively counted as two episodes.
} 
frequent in the second and fourth quartile. Nonetheless, the estimated effects are not significant once we contemporaneously control for income levels (columns 5). ${ }^{12}$ Similarly, a dummy identifying those countries with democracy above the median in the sample is not significant (column 6). Instead, a dummy for whether the country experienced continuous "perfect" democracy throughout the whole decade (i.e. whether the democracy index was equal to 10 for the whole decade) is significantly associated with lower occurrence of mass killings. This association survives the inclusion of income in the regression, both linearly and quadratically (columns 7 and 8). The effect is large. According to the point estimate, a jump towards "perfect" democracy would be associated with about 2/3 reduction in the probability of massacres (a decrease of 0.11 points from a sample average of 0.17$)$. As for income, (log) GDP is in general negatively and significantly associated with the occurrence of mass killings. In particular, a quadratic specification seems to fit the data particularly well. The estimates suggest that the chances of massacres increase for income levels below about $\$ 900$ per capita (corresponding to the lowest income quartile in the whole sample), while they decrease afterwards. The quadratic specification for income seems fairly robust to controlling for democracy in alternative ways. P-values associated with the likelihood ratio test are reported at the bottom of columns 4-7. ${ }^{13}$

A natural extension would be to control for both income and democracy flexibly. When we include in the regression dummies for democracy and income quartiles,

\footnotetext{
${ }^{12}$ If income is excluded from the set of regressors, mass killings are significantly less frequent among the countries in the fourth quartile of democracy.

${ }^{13}$ A rule of thumb indicates that this specification seems to predict the probability of the outcomes fairly well ( $83 \%$ of the cases).
} 
massacres appear to be less frequent in countries at the highest income quartiles but, not significantly so in countries at the highest democracy quartile (column 9).

The simple correlations between mass killings and income suggest that this relationship has changed over time. In the XIXth century, mass killings were more likely in relatively richer countries, while in the XXth century, mass killings more likely to occur in poorer countries. This is not surprising when one realizes that many of the mass killings episodes in the XIXth were perpetrated by rich countries' governments in the process of establishing their authority on the colonies. In the XXth century, instead, mass killings tend to occur more frequently in relatively less developed countries. A similar unconditional result obtains for democracy. We explore these issues in detail in table 3.

First, we refine our basic specification by adding pre- and post- World Wars dummies. None of these is significant. Then we restrict the sample to the XX century. As before, we experiment with different specifications, including quadratic and linear income, and non-linear forms for both income and democracy (columns 2-5). Quadratic income has now a weaker fit, while linear income produces better estimates. Overall, it appears that mass killings in the XXth century are significantly less frequent in countries at the top quartiles of democracy and economic development. (column 5).

We are also able to explore the role of a few other potentially relevant correlates. For example, a growing body of literature has analyzed the role of ethnic fractionalization as an impediment to effective public policies and, ultimately, to economic growth and as a determinant of civil war (see for example Easterly and Levine, 1997, who discuss the role of ethnic fractionalization in “Africa’s growth tragedy” and Collier and Hoeffler, 1999, who analyze the role of fractionalization in the context of civil wars). In our 
analysis, understanding the role of the ethnic structure of a country is particularly relevant, especially as most of the episodes are classified as "ethnic or communal" killings. When we add to the basic specification the measure of ethnic fractionalization developed by Alesina et al. (2003), we find that the probability of mass killings is related quadratically to fractionalization. In particular, the chances of mass killing increase at levels of fractionalization below 0.46 , a value slightly above the sample mean, and decrease thereafter (column 6). The fractionalization measure captures the probability that two randomly selected individuals will belong to different ethnic groups. Hence, a situation in which there are two groups with equal shares in the population would have a fractionalization index of 0.5 , close to the maximum threat of massacres. A more ethnically fractionalized situation with many small groups may be less likely to erupt in killings of one group by another than one with fewer and larger groups.

Finally, we are able to correlate episodes of mass killings with indicator dummies for civil wars and colonial, imperial or international wars. ${ }^{14}$ We find mass killings to be significantly more frequent during civil wars, and marginally so during colonial, imperial or international wars.

\section{V.2 What makes episodes of mass killing more cruel?}

We collected data on the estimated number of deaths associated with each mass killings episode. There is a substantial uncertainty on the estimated number of victims. For most episodes, we have interval estimates of minimum and maximum number of killings; sometimes, instead, the source reported average number of deaths. Our measure

\footnotetext{
${ }^{14}$ Note that these indicators were built independently from our mass killings variable (Singer and Small, 1994).
} 
of the number of victims is the average number of deaths, where the maximum (minimum) of the range is the maximum (minimum) number of deaths among all of the sources we draw upon. Given the large variation in the nature and magnitude of the episodes (combined with the presence of substantial outliers), using a log transformation of the data seemed a sensible choice.

Figures 6 and 7 depict unconditional relationships between (log of) average killings and, respectively, democracy and income per capita.

We apply tobit analysis to explore the relationship between the magnitude of mass killings, per capita income, and democracy. In parallel with the probit analysis, we experiment with different specifications - including linear and quadratic income, and non-linear specifications in democracy. All of the specifications include the (log of) population in order to provide a scale for the size of the country, and a dummy for whether the episode occurred in the XXth century.

The results, reported in table 4, suggest that there is evidence for an inverted Ushaped relationship between per capita income and killings. In particular, the number of victims peaks at around $\$ 1300$ of per capita income (slightly below the sample average). In general, we find the magnitude of mass killing to be negatively associated with DEMOCRACY, but the weak statistical significance does not allow meaningful inferences.

We then investigate the relationship between income and killings allowing for different slopes in the XIXth and XXth century (table 5). We find that the quadratic relationship between income and killings still holds. Moreover, and more importantly, 
democracy is now linearly associated with a lower number of victims (at the $10 \%$ level of significance, column 1).

Interestingly, we find no relationship between the magnitude of mass killings and ethnic fractionalization, while mass killings appear to be substantially larger if the episode occurred within a civil or international war (columns 2-5).

\section{3 Robustness checks}

We test the robustness of our results by performing estimation under a set of alternative assumptions.

To the extent that we are interested in income as an explanatory variable for occurrence of mass killings, using interpolated income might introduce a further element of endogeneity in the relationship - episodes of massacres might cause substantial economic disruptions and drops in income, with the last occurring at different rates in different countries. In the context of our analysis, this potential problem should be weighed against the benefit of being able to work with a larger sample size and a more substantial representation of countries in the XIXth century. However, in order to make sure that our results are not driven by interpolation we run all of our regressions over the non-interpolated sample. We find that our main result related to income - that occurrence and magnitude of mass killings has a quadratic relationship with income - hold.

Similarly, results are virtually unchanged if lagged values of income and democracy are entered in the specification instead of contemporaneous values. These findings are reassuring but we do not claim that this resolves the intractable problem of causality between income (or democracy) and mass killings. We interpret our results as suggestive associations rather than decisive indications of causality. 
One might also argue that our results are a product of the arbitrary decision of organizing the data by decades. To verify that this is not the case, we run all of our regressions on data organized by twenty-year periods. Here as well, our main results hold. Moreover, the organization of the data in ten year periods generates a possible builtin over-counting of episodes, when episodes start in one decade and finish in the following decade. To make sure that our results are not driven by any double counting of episodes, we run our probit specifications using as a dependent variable a dummy taking value of one in the decade when an episode began and zero otherwise. Also in this case, the quadratic relationship between income and mass killing occurrence persists and, similarly to the results reported in the previous tables, no linear relationship emerges between mass killings and democracy.

Finally, one could object that our data includes very heterogeneous episodes, particularly as the number of victims is concerned. Moreover, as we previously discussed, non-democratic governments might have made efforts to keep episodes of mass killings secret, implying potentially important selection issues for our right-hand side variable. However, we expect that episodes involving a relatively small number of victims will be more likely to remain secret, while large-scale episodes will sooner or later become known. To ensure that our results can be generalized beyond these concerns, we constructed two 0/1 variables that excluded, respectively, episodes with fewer than 200 and 500 victims. Our probit results are robust to the use of these alternative dependent variables.

All of these results are not reported in the text but are available upon request. 


\section{Conclusions}

In this paper we analyze the determinants of mass killings of unarmed civilians in the period from 1820 to 1998. To do so, we built a new data set (and the first one to our knowledge spanning for such a long time series) where we systematize episodes of mass killing and we study their relationship with the level of development and democracy across countries.

We find that episodes of mass killing are more likely at intermediate levels of income and are less frequent only at the highest levels of democracy - only countries scoring a perfect 10 (the highest level in our index) for the whole decade, appeared to have a lower chance of mass killings once we controlled for their income levels. This finding is surprising, especially in light of the vast literature that indicates lack of democracy as a necessary (though not sufficient) condition for gross human rights violations. However, we should be clear that lack of significance of democracy over most of its range is not the same as proof that democracy does not matter over this range; it is a lack of evidence that the effect of democracy over this range is nonzero rather than positive evidence that the effect is indeed zero.

A closer look at the data reveals that a number of massacre episodes were perpetrated by highly democratic countries. Most of these though are concentrated in the XIXth century, when these countries were engaged in colonial expansion. When we restrict attention to the XXth century only, we find, more reassuringly, that countries in the highest quartile of democracy are significantly less likely to be engaged in mass killings. We should note, however, that, even in this context, the relationship between the likelihood of a massacre and democracy is not linear, implying that we have only found evidence that an improvement in the openness of institutions translates into a lower 
chance of massacres when countries move to the highest level of democracy. Finally, we find that in the XXth century, discrete improvements in democracy were associated with less cruel massacre episodes.

Our results are subject to a number of qualifications. First, as we are dealing with cross country estimates, there might be a number of confounding, unmeasured factors that make a causal interpretation of our results problematic. Second, and more important, the definition (and index) of democracy we adopt is limited to some specific features of the political process, namely the openness of political institutions. In democracies the majority has voice and representation and the fairness or openness of political institutions does not necessarily imply fair outcomes, unless specific clauses are embedded in the institutional setting (for example requiring qualified majority voting in the parliament, etc.). One should also note that in most cases of massacres perpetuated by democratic governments, the victims were not "voters" - in case of massacres in the imperialist period, they were citizens of the colonies, and even when the massacres were directed towards people within the polity (for example the Native Americans in North America), the victims did not have voting rights. One policy implication of our findings could be that democracy - an essential precondition - should be supplemented by human rights protection and other guarantees of individual rights to bring about beneficial outcomes for all. 
Figure 1. Mass killing frequency at different quartiles of development (log of GDP per capita)

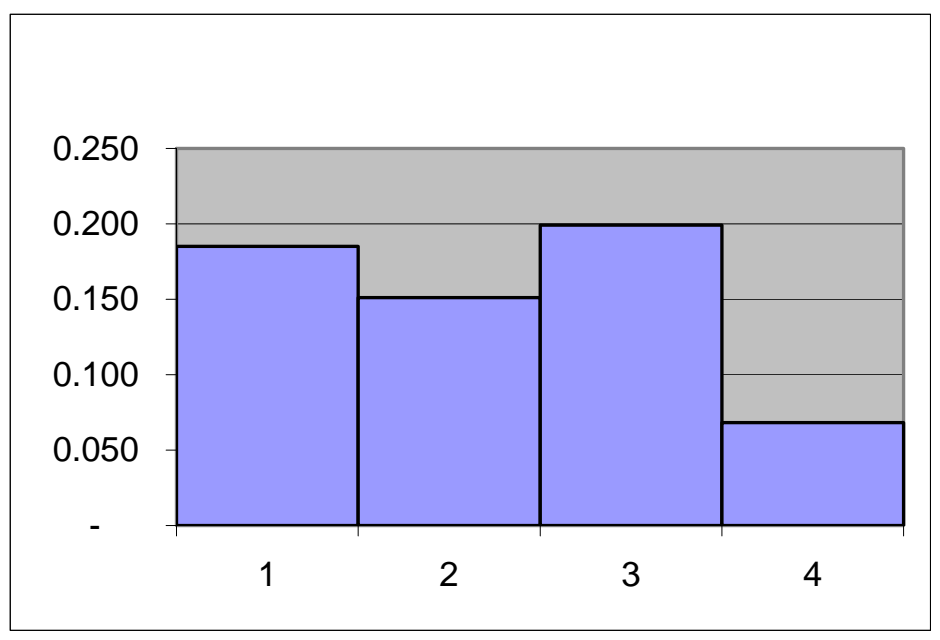

Figure 2. Mass killings frequency at different quartiles of democracy

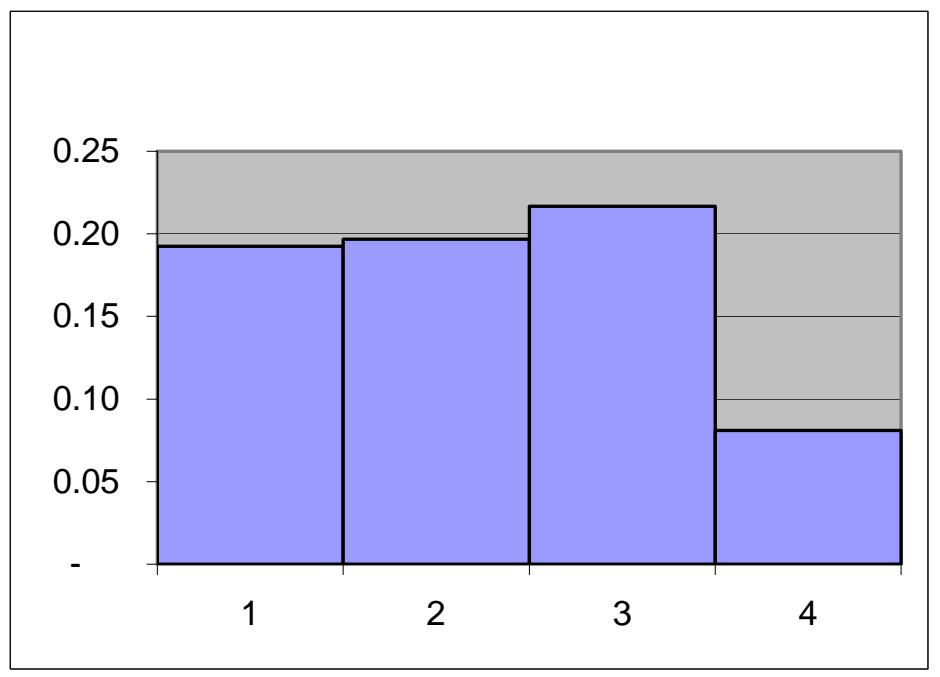


Figure 3. Average number of victims by quartiles of development (log of GDP per capita)

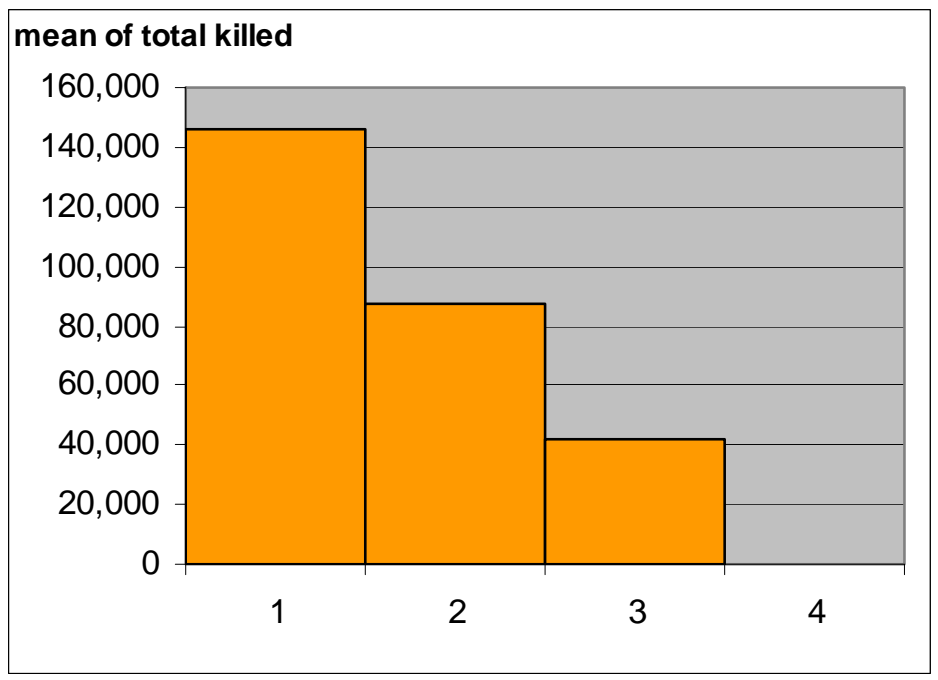

Figure 4. Average number of victims by quartiles of democracy

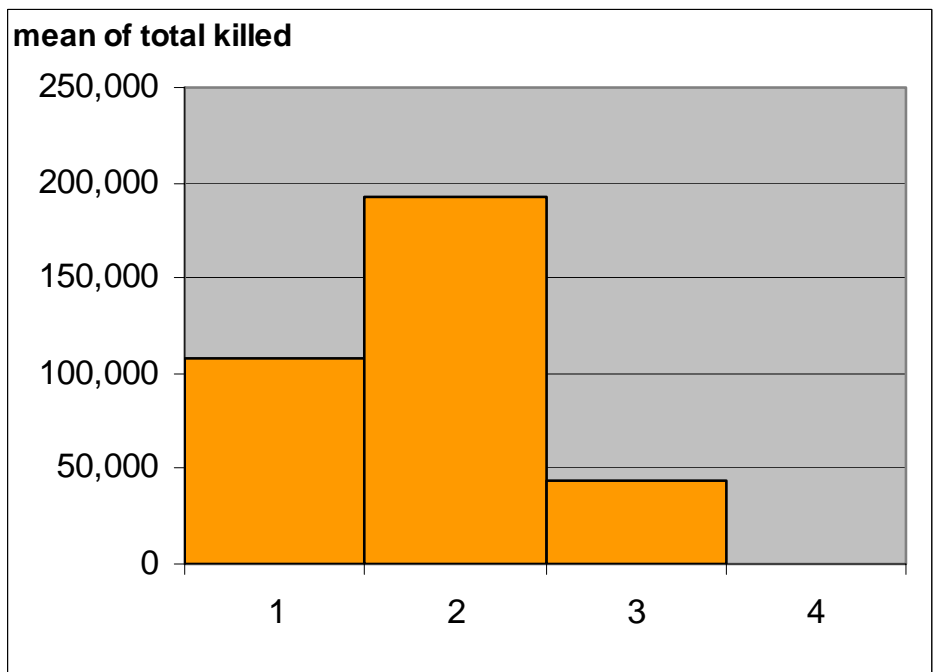


Figure 5. Absolute number of victims by democracy quartiles

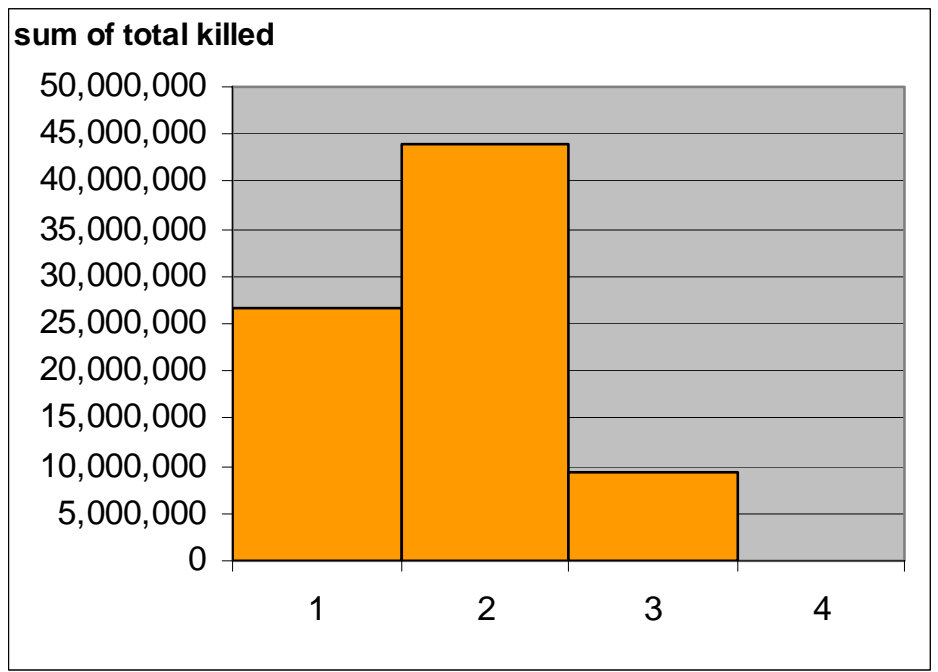


Figure 6. Average magnitude of mass killing episodes per decade (in logs) and per capita gdp (in logs)

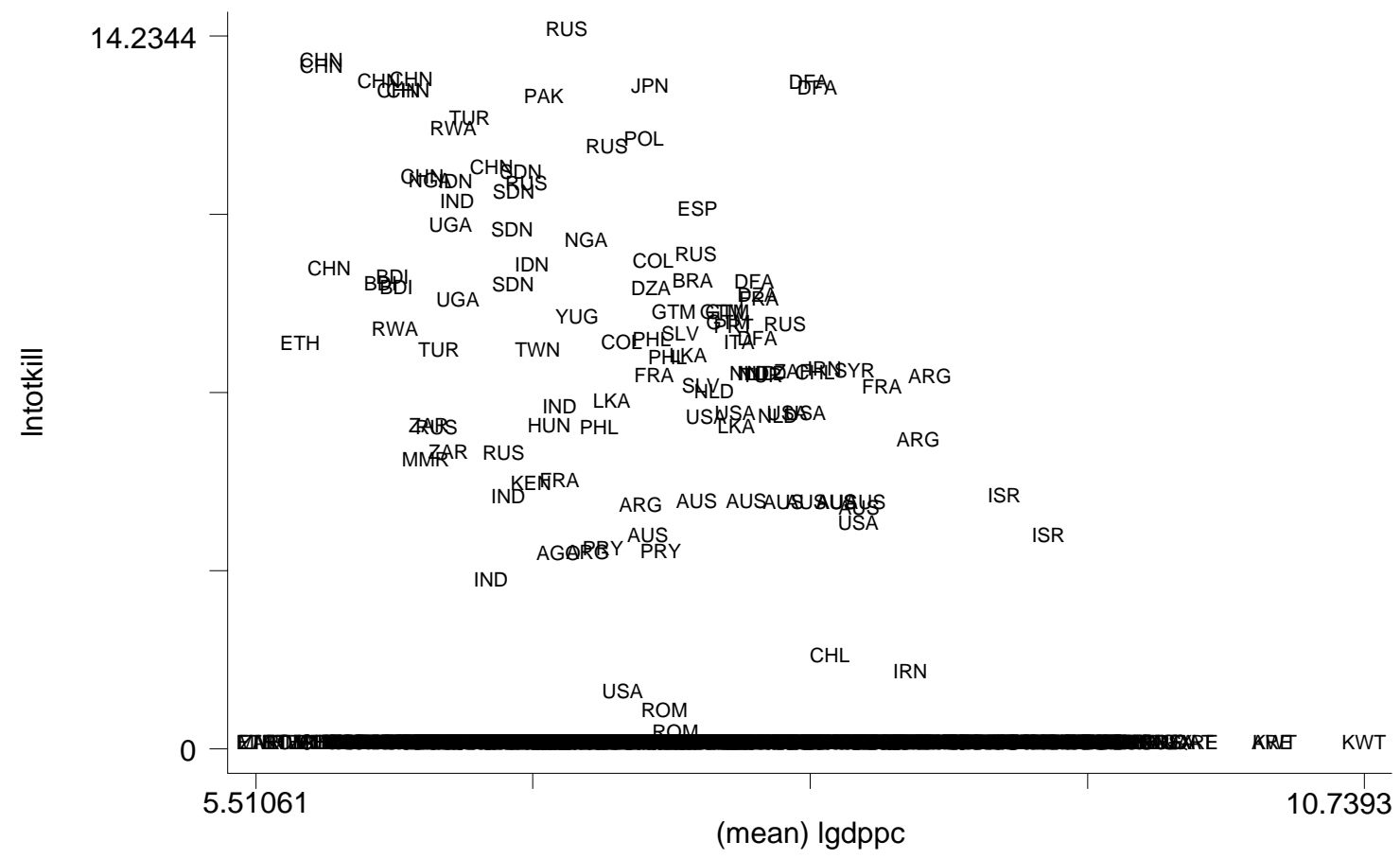

Figure 7. Average magnitude of mass killing episodes per decade (in logs) and levels of democracy

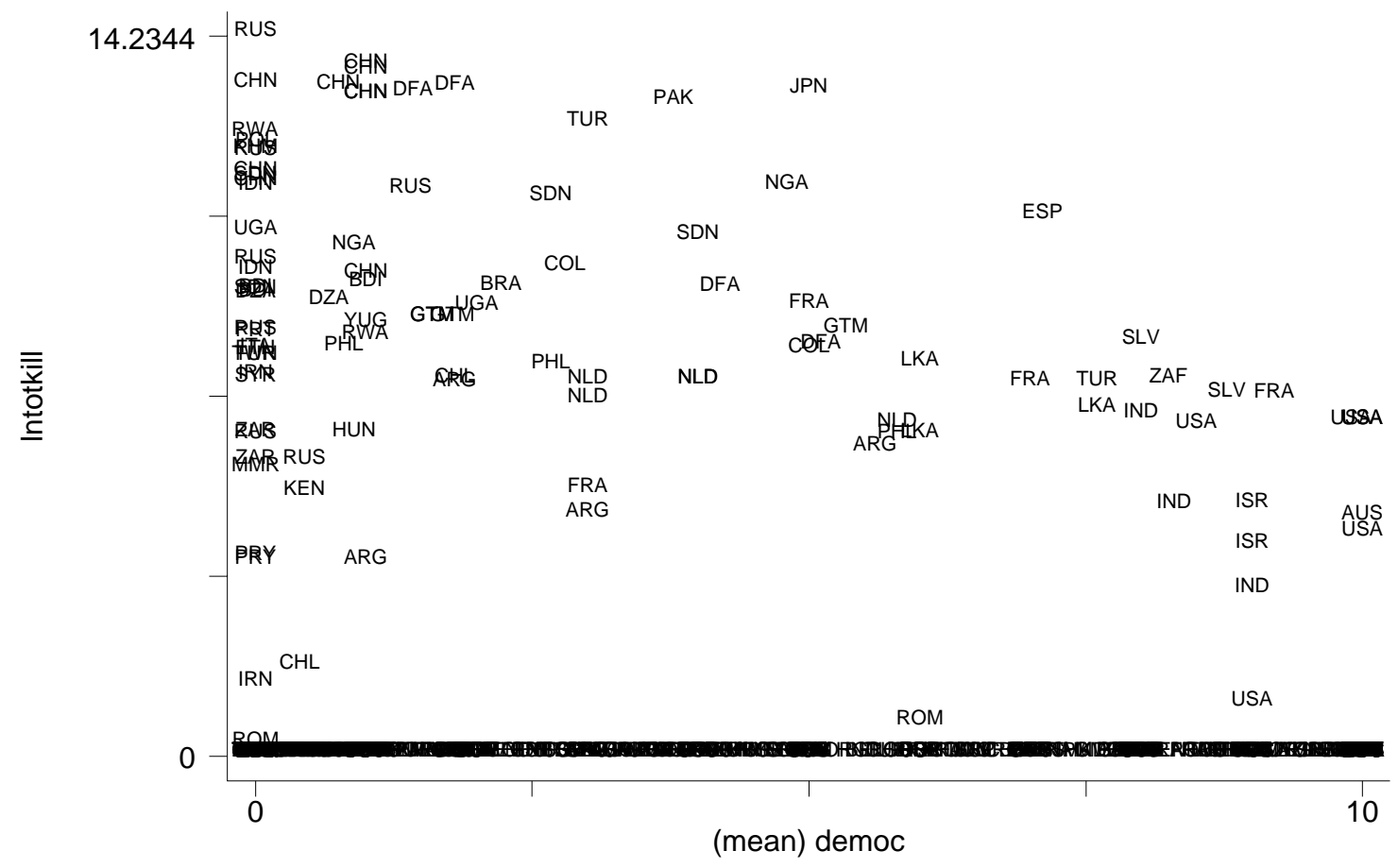


Table 2. Basic probit analysis. Dependent variable equals 1 if a mass killings episode occurred in a decade, 0 otherwise.

\begin{tabular}{|c|c|c|c|c|c|c|c|c|c|}
\hline & $(1)$ & $(2)$ & $(3)$ & (4) & $(5)$ & $(6)$ & $(7)$ & $(8)$ & (9) \\
\hline XX century & $\begin{array}{l}0.02 \\
(0.38)\end{array}$ & $\begin{array}{l}0.05 \\
(0.79)\end{array}$ & $\begin{array}{l}0.05 \\
(0.82)\end{array}$ & $\begin{array}{l}0.06 \\
(1.13)\end{array}$ & $\begin{array}{l}0.05 \\
(1.01)\end{array}$ & $\begin{array}{l}0.06 \\
(1.12)\end{array}$ & $\begin{array}{l}0.05 \\
(0.83)\end{array}$ & $\begin{array}{l}0.05 \\
(1.03)\end{array}$ & $\begin{array}{l}0.05 \\
(0.87)\end{array}$ \\
\hline DEMOCRACY & $\begin{array}{l}-0.01^{*} \\
(1.84)\end{array}$ & & $\begin{array}{l}0.00 \\
(0.31)\end{array}$ & $\begin{array}{l}0.0018 \\
(0.58)\end{array}$ & & & & & \\
\hline LGDPPC & & $\begin{array}{l}-0.07 * * * \\
(4.17)\end{array}$ & $\begin{array}{l}-0.07^{* * *} \\
(3.32)\end{array}$ & $\begin{array}{l}0.70^{* *} \\
(2.28)\end{array}$ & $\begin{array}{l}0.65^{* *} \\
(1.98)\end{array}$ & $\begin{array}{l}0.67^{* * *} \\
(2.26)\end{array}$ & $\begin{array}{l}-0.03 * \\
(1.69)\end{array}$ & $\begin{array}{l}0.51 \\
(1.60)\end{array}$ & \\
\hline LGDPPC2 & & & & $\begin{array}{l}-0.05^{* *} \\
(2.49)\end{array}$ & $\begin{array}{l}-0.05^{* *} \\
(2.14)\end{array}$ & $\begin{array}{l}-0.05^{* *} \\
(2.51)\end{array}$ & & $\begin{array}{l}-0.04 * \\
(1.71)\end{array}$ & \\
\hline DEMO10 & & & & & & & $\begin{array}{l}-0.13^{* * *} \\
(2.61)\end{array}$ & $\begin{array}{l}-0.11^{*} \\
(1.80)\end{array}$ & \\
\hline DEMO_HIGH & & & & & & $\begin{array}{l}0.03 \\
(0.99)\end{array}$ & & & \\
\hline DEMO_QUART==2 & & & & & $\begin{array}{l}-0.01 \\
(0.46)\end{array}$ & & & & $\begin{array}{l}-0.01 \\
(0.45)\end{array}$ \\
\hline DEMO_QUART ==3 & & & & & $\begin{array}{l}0.01 \\
(0.44)\end{array}$ & & & & $\begin{array}{l}0.01 \\
(0.24)\end{array}$ \\
\hline DEMO_QUART $==4$ & & & & & $\begin{array}{l}-0.01 \\
(0.18)\end{array}$ & & & & $\begin{array}{l}-0.04 \\
(0.72)\end{array}$ \\
\hline LGDPPC_QUART==2 & & & & & & & & & $\begin{array}{l}-0.03 \\
(0.75)\end{array}$ \\
\hline LGDPPC_QUART ==3 & & & & & & & & & $\begin{array}{l}0.01 \\
(0.12)\end{array}$ \\
\hline LGDPPC_QUART ==4 & & & & & & & & & $\begin{array}{l}-0.14^{* * *} \\
(2.64)\end{array}$ \\
\hline LPOP & $\begin{array}{l}0.07 * * * \\
(6.13)\end{array}$ & $\begin{array}{l}0.06 * * * \\
(5.62)\end{array}$ & $\begin{array}{l}0.06 * * * \\
(5.60)\end{array}$ & $\begin{array}{l}0.07 * * * \\
(6.04)\end{array}$ & $\begin{array}{l}0.07 * * * \\
(5.91)\end{array}$ & $\begin{array}{l}0.07 * * * \\
(6.05)\end{array}$ & $\begin{array}{l}0.06^{* * *} \\
(5.91)\end{array}$ & $\begin{array}{l}0.06 * * * \\
(5.93)\end{array}$ & $\begin{array}{l}0.07 * * * \\
(6.01)\end{array}$ \\
\hline $\begin{array}{l}\text { LR test, } \\
\text { P-value for } \\
\text { lgdppc\&lgdppc2==0 }\end{array}$ & & & & 0.00 & 0.00 & 0.00 & & 0.00 & \\
\hline Observations & 906 & 902 & 902 & 902 & 902 & 902 & 902 & 902 & 902 \\
\hline
\end{tabular}


Table 4. Probit analysis. XX century sample and additional correlates.

\begin{tabular}{|c|c|c|c|c|c|c|c|}
\hline & $(1)$ & $(2)$ & (3) & $(4)$ & (5) & $(6)$ & $(7)$ \\
\hline $\begin{array}{l}\text { Sample } \\
\text { Betweenwars }\end{array}$ & $\begin{array}{l}\text { Full } \\
-0.10 \\
(0.32)\end{array}$ & & $\mathrm{XX} \mathrm{c}$ & ntury & & & \\
\hline WWII & $\begin{array}{l}0.37 \\
(1.16)\end{array}$ & & & & & & \\
\hline postWWII & $\begin{array}{l}0.33 \\
(1.39)\end{array}$ & & & & & & \\
\hline XX century & & & & & & $\begin{array}{l}0.05 \\
(0.94)\end{array}$ & $\begin{array}{l}0.05 \\
(0.89)\end{array}$ \\
\hline DEMOCRACY & $\begin{array}{l}0.02 \\
(0.87)\end{array}$ & $\begin{array}{l}-0.03 \\
(1.30)\end{array}$ & & & & & \\
\hline LGDPPC & $\begin{array}{l}3.49 * * \\
(2.46)\end{array}$ & $\begin{array}{l}-0.31^{* * *} \\
(3.63)\end{array}$ & $\begin{array}{l}0.25 \\
(0.88)\end{array}$ & $\begin{array}{l}-0.05^{* *} \\
(2.52)\end{array}$ & & $\begin{array}{l}0.52 \\
(1.64)\end{array}$ & $\begin{array}{l}0.48 \\
(1.49)\end{array}$ \\
\hline LGDPPC2 & $\begin{array}{l}-0.26^{* * *} \\
(2.67)\end{array}$ & & $\begin{array}{l}-0.02 \\
(1.05)\end{array}$ & & & $\begin{array}{l}-0.04^{*} \\
(1.79)\end{array}$ & $\begin{array}{l}-0.03 \\
(1.55)\end{array}$ \\
\hline DEMO10 & & & $\begin{array}{l}-0.12 * \\
(1.94)\end{array}$ & $\begin{array}{l}-0.14^{* *} \\
(2.42)\end{array}$ & & $\begin{array}{l}-0.10 * \\
(1.72)\end{array}$ & $\begin{array}{l}-0.08 \\
(1.34)\end{array}$ \\
\hline DEMO_QUART==2 & & & & & $\begin{array}{l}-0.01 \\
(0.38)\end{array}$ & & \\
\hline DEMO_QUART ==3 & & & & & $\begin{array}{l}-0.02 \\
(0.55)\end{array}$ & & \\
\hline DEMO_QUART ==4 & & & & & $\begin{array}{l}-0.11 * * \\
(2.10)\end{array}$ & & \\
\hline LGDPPC_QUART==2 & & & & & $\begin{array}{l}-0.06^{*} \\
(1.77)\end{array}$ & & \\
\hline LGDPPC_QUART ==3 & & & & & $\begin{array}{l}-0.04 \\
(0.97)\end{array}$ & & \\
\hline LGDPPC_QUART ==4 & & & & & $\begin{array}{l}-0.13^{* * *} \\
(2.81)\end{array}$ & & \\
\hline $\mathrm{EF}$ & & & & & & $\begin{array}{l}0.57 * \\
(1.89)\end{array}$ & \\
\hline EF2 & & & & & & $\begin{array}{l}-0.66 * * \\
(2.01)\end{array}$ & \\
\hline CWAR_D & & & & & & & $\begin{array}{l}0.30 * * * \\
(6.82)\end{array}$ \\
\hline CIIWAR_D & & & & & & & $\begin{array}{l}0.06^{*} \\
(1.88)\end{array}$ \\
\hline LPOP & $\begin{array}{l}0.31^{* * * *} \\
(6.27)\end{array}$ & $\begin{array}{l}0.30 * * * \\
(5.59)\end{array}$ & $\begin{array}{l}0.06 * * * \\
(5.78)\end{array}$ & $\begin{array}{l}0.06 * * * \\
(5.83)\end{array}$ & $\begin{array}{l}0.07 * * * \\
(5.66)\end{array}$ & $\begin{array}{l}0.06 * * * \\
(5.67)\end{array}$ & $\begin{array}{l}0.05^{* * * *} \\
(4.47)\end{array}$ \\
\hline Observations & 902 & 743 & 743 & 743 & 743 & 899 & 902 \\
\hline
\end{tabular}

Dependent variable equals 1 if an episode of mass killing occurred in the decade, 0 otherwise. Robust $\mathrm{z}$ statistics in parentheses. * significant at $10 \%$; ${ }^{* *}$ significant at $5 \%$; ** significant at $1 \%$. 
Table 4. Basic tobit analysis. Dependent variable (log) average number of victims in a decade.

\begin{tabular}{|c|c|c|c|c|}
\hline & $(1)$ & $(2)$ & $(3)$ & $(4)$ \\
\hline XX century & $\begin{array}{l}0.33 \\
(1.11)\end{array}$ & $\begin{array}{l}0.28 \\
(1.07)\end{array}$ & $\begin{array}{l}0.30 \\
(1.27)\end{array}$ & $\begin{array}{l}0.27 \\
(1.21)\end{array}$ \\
\hline DEMOCRACY & $\begin{array}{l}-0.029 \\
(1.07)\end{array}$ & & $\begin{array}{l}-0.01 \\
(0.70)\end{array}$ & \\
\hline LGDPPC & $\begin{array}{l}-0.20^{*} \\
(1.88)\end{array}$ & $\begin{array}{l}-0.08 \\
(0.77)\end{array}$ & $\begin{array}{l}3.81 * * \\
(2.23)\end{array}$ & $\begin{array}{l}2.76 \\
(1.61)\end{array}$ \\
\hline LGDPPC2 & & & $\begin{array}{l}-0.26 * * \\
(2.35)\end{array}$ & $\begin{array}{l}-0.19 * \\
(1.67)\end{array}$ \\
\hline DEMO10 & & $\begin{array}{l}-0.65^{* * *} \\
(2.80)\end{array}$ & & $\begin{array}{l}-0.50 * \\
(1.86)\end{array}$ \\
\hline LPOP & $\begin{array}{l}0.39 * * * \\
(7.37)\end{array}$ & $\begin{array}{l}0.36^{* * *} \\
(7.70)\end{array}$ & $\begin{array}{l}0.39 * * * \\
(7.58)\end{array}$ & $\begin{array}{l}0.36 * * * \\
(7.45)\end{array}$ \\
\hline $\begin{array}{l}\text { LR test, } \\
\text { P-value for } \\
\text { lgdppc\&lgdppc } 2==0\end{array}$ & & & 0.00 & 0.06 \\
\hline Observations & 846 & 846 & 846 & 846 \\
\hline
\end{tabular}

Robust $\mathrm{z}$ statistics in parentheses * significant at $10 \%$; $* *$ significant at $5 \%$; $* * *$ significant at $1 \%$. Marginal coefficients are reported (unconditional expected value). 
Table 5. Tobit analysis. XX century sample and additional correlates.

\begin{tabular}{|c|c|c|c|c|c|}
\hline & $(1)$ & $(2)$ & (3) & $(4)$ & (5) \\
\hline Sample & & ntury & \multirow{2}{*}{\multicolumn{3}{|c|}{ Full }} \\
\hline DEMOCRACY & $\begin{array}{l}-0.04^{*} \\
(1.86)\end{array}$ & $\begin{array}{l}-0.05^{* *} \\
(2.22)\end{array}$ & & & \\
\hline LGDPPC & $\begin{array}{l}2.98^{*} \\
(1.79)\end{array}$ & $\begin{array}{l}-0.23^{* *} \\
(2.26)\end{array}$ & $\begin{array}{l}2.28^{*} \\
(1.67)\end{array}$ & $\begin{array}{l}1.94 \\
(1.47)\end{array}$ & $\begin{array}{l}2.56^{* * *} \\
(1.52)\end{array}$ \\
\hline LGDPPC2 & $\begin{array}{l}-0.21^{*} \\
(1.92)\end{array}$ & & $\begin{array}{l}-0.15 \\
(1.63)\end{array}$ & $\begin{array}{l}-0.12 \\
(1.45)\end{array}$ & $\begin{array}{l}-0.18^{* *} \\
(1.62)\end{array}$ \\
\hline LPOP & $\begin{array}{l}0.38 * * * \\
(7.27)\end{array}$ & $\begin{array}{l}0.40 * * * \\
(7.08)\end{array}$ & $\begin{array}{l}0.26^{* * *} \\
(5.88)\end{array}$ & $\begin{array}{l}0.21^{* * *} \\
(5.08)\end{array}$ & $\begin{array}{l}0.34^{* * *} \\
(6.51)\end{array}$ \\
\hline XX century & & & $\begin{array}{l}0.18 \\
(0.97)\end{array}$ & $\begin{array}{l}0.21 \\
(1.13)\end{array}$ & $\begin{array}{l}0.31 \\
(1.33)\end{array}$ \\
\hline EF & & & & & $\begin{array}{l}1.53 \\
(1.01)\end{array}$ \\
\hline EF2 & & & & & $\begin{array}{l}-2.11 \\
(1.21)\end{array}$ \\
\hline DEMO10 & & & $\begin{array}{l}-0.35 \\
(1.41)\end{array}$ & $\begin{array}{l}-0.33 \\
(1.47)\end{array}$ & $\begin{array}{l}-0.47 \\
(-1.80)\end{array}$ \\
\hline CWAR_D & & & $\begin{array}{l}1.98 * * * \\
(8.37)\end{array}$ & $\begin{array}{l}1.97 * * * \\
(8.18)\end{array}$ & \\
\hline CIIWAR_D & & & & $\begin{array}{l}0.42 * * * \\
(2.62)\end{array}$ & \\
\hline Observations & 698 & 698 & 846 & 846 & 843 \\
\hline
\end{tabular}




\section{Bibliography}

Alesina, Alberto, Arnaud Devleeschauwer, William Easterly, Sergio Kurlat, and Romain Wacziarg (2003). "Fractionalization," Journal of Economic Growth 8, no. 2, 155-194

Andreopoulos, George (ed.) (1994). Genocide: Conceptual and Historical Dimensions, Philadelphia, University of Pennsylvania Press.

Azam, J.-P., and Anke Hoeffler (2002). "How Much Civil War Will We See? Explaining the Prevalence of Civil War,” Journal of Conflict Resolution, 46(3): 307-34.

Bachman, Ronald (ed.) (1989). Romania: a Country Study, Library of Congress.

Bell-Fialkoff, Andrew (1996). Ethnic Cleansing, St. Martin's Press.

Bickerton, Ian and Carla Klausner (1998). A Concise History of the Arab-Israeli Conflict, Prentice Hall, NJ, USA.

Burant, Stephen (ed.) (1989). Hungary: a Country Study, Library of Congress.

Campbell, Kenneth J. (1999). Genocide \& the Global Village, Saint Martin's Press LLC.

Campbell, Kenneth J. (1997). "Genocide and the new world order," Injustice Studies, November.

Carnegie Commission on Preventing Deadly Conflict (1997). Preventing Deadly Conflict, New York: Carnegie Corporation of New York.

Chalk, Frank and Kurt Jonassohn (1990). The History \& Sociology of Genocide: Analyses \& Case Studies, Yale University Press.

Charny, Israel (1982). How Can We Commit the Unthinkable? Genocide: The Human Cancer Boulder CO: Westview Press.

Charny, Israel (ed.) (1999). Encyclopedia of Genocide (volumes I and II), A B C-CLIO Incorporated.

Chorbajian, Levon and George Shirinian (eds) (1998). Studies in Comparative Genocide, New York: St. Martin's Press.

Collelo, Thomas (ed.) (1989). Angola: a country study, Library of Congress.

Collier, P. (1999). “On the Economic Consequences of Civil War,” Oxford Economic Papers, 51: 168-83. 
Collier, Paul and Anke Hoeffler (2004). "Greed and Grievance in Civil Wars,” Oxford Economic Papers, 56: 663-595 (2002a). “Aid, Policy, and Peace: Reducing the Risks of Civil Conflict,” Defence and Peace Economics, 13(6): 435-50. (2002b). “On the Incidence of Civil War in Africa," Journal of Conflict Resolution, 46(1): 13-28.

573 (1998). “On Economic Causes of Civil War,” Oxford Economic Papers , 50: 563-

Cordesman, Anthony (1994). Iraq’s Military Forces: 1988-1993, CSIS.

Dobkowski, Michael N. and Isidor Wallimann (eds) (1992). Genocide in Our Time: An Annotated Bibliography with Analytical Introductions, Resources on Contemporary Issues, Pierian Press.

Edelheit, A. and H. Edelheit (1994). History of the Holocaust, Westview Press.

Fein, Helen (1993). Genocide: A Sociological Perspective, London: Sage for the International Sociological Association.

Fein, Helen (ed.) (1992). Genocide Watch, New Haven \& London: Yale University Press.

Freedom House (2001). The World's Most Repressive Regimes, Report to the 57th Session of the U.N. Commission on Human Rights.

Friedrichs, David O. (1998). State Crime I, Brookfield VT: Ashgate.

Friedrichs, David O. (1998). State Crime II, Brookfield VT: Ashgate.

Galbraith, James K. and George Purcell (1998). Inequality and State Violence: A Preliminary Report, Economics Research Network (ERN).

Haggarty, Richard (ed.) (1988). El Salvador: a country study, Library of Congress.

Harff, Barbara (1987). "The State as Mass Murderer: A Theory of Genocides and Politicides,” Manuscript.

Harff, Barabara (1992). "Recognizing Genocides and Politicides," in Helen Fein (ed.) Genocide Watch, New Haven \& London: Yale University Press.

Harff, Barbara and Ted Gurr (1995)."Victims of the State: Genocide, Politicides, and Group Repression from 1945 to 1995,” Manuscript. 
Horowitz, Irving L.(1997). Taking lives: Genocide and State Power (4th ed. Rev.), New Brunswick NJ: Transaction Publishers.

Human Rights Watch (1995). Slaughter Among Neighbors: The Political Origins of Communal Violence, New Haven \& London: Yale University Press.

Jonassohn, Kurt and Karin Bjornson (1997). Genocide \& Gross Human Rights Violations, Transaction Publishers.

Kahan, I., A. Barak and Efrat, Y. (1983). Kahan Report, Commission of Inquiry into the Events at the Refugee Camps in Beirut.

Kebbede, G. (ed.) (1999). Sudan's Predicament: Civil War, Displacement And Ecological Degradation, Ashgate.

Klier, J. and S. Lambroza (1992). Pogroms: Anti-Jewish Violence in Modern Russian History, Cambridge U. Press.

Krain, Matthew (1997). "State-Sponsored Mass Murder: The Onset and Severity of Genocides and Politicides,” Journal of Conflict Resolution 41 (3) 331-360.

Kressel, Neil J. (1996). Mass Hate: The Global Rise of Genocide and Terror,New York: Plenum Press.

Kuper, Leo (1981). Genocide: Its Political Use in the Twentieth Century, New Haven \& London: Yale University Press.

Levene, Mark and Penny Roberts (1998). The Massacre in History, Berghahn Books, Incorporated.

Melson, Robert F. (1992). Revolution and genocide, Chicago: University of Chicago Press.

Metz, Helen Chapin (ed.) (1991). Sudan: a country study, Library of Congress.

Metz, Helen Chapin (ed.) (1995). Turkey: a country study, Library of Congress.

Neier, Aryeh (1998). War Crimes: Brutality Genocide Terror and The Struggle For Justice, New York: Times Books/Random House.

Ofcansky, Thomas and Berry LaVerle (ed.) (1991). Ethiopia: a country study, Library of Congress.

Porter, Jack N. (ed) (1997). Genocide \& Human Rights: A Global Anthology, Holocaust Studies, Reprint Spencer Press. 
Reynal-Querol, M. (2002a). “Ethnicity, Political Systems, and Civil War,” Journal of Conflict Resolution, 46(1): 29-54.

Reynal-Querol, M. (2002b). “Political Systems, Stability, and Civil Wars,” Defence and Peace Economics, 13(6): 465-83.

Rosenbaum, Alan S. (1997). Is the Holocaust Unique?, Perspectives on Comparative Genocide, Westview Press.

Rubenstein, Richard L., Michael Dobrowski, and Isidor Wallimann (2000) (eds.). Genocide \& the Modern Age: Etiology and Case Studies of Mass Death, Syracuse University Press.

Rummel, R. J. (1994). “Democracy Power Genocide and Mass Murder,” Journal of Conflict Resolution, 39(1): 3-26, March.

Rummel, R. J. (1994). “Power Genocide and Mass Murder,” Journal of Peace Research, 31 (1) 1-10.

Rummel, R.J. (1997). Death by Government, New Brunswick NJ: Transaction Publishers.

Rummel, R.J. (1997). Statistics of Democide, Charlottesville VA: Center for National Security Law.

Rummel, R. J. (1997). Power Kills: Democracy as a Method of Nonviolence. New Brunswick NJ: Transaction Publishers.

Scheper-Hughes, Nancy (1996). "Small Wars and Invisible Genocides,” Social Science \& Medicine, 43 (5), 889-900.

Scherrer, Christian P. (1999). “Towards a Theory of Modern Genocide. Comparative Genocide Research: Definitions, Criteria, Typologies, Cases, Key Elements, Patterns, and Voids,” Journal of Genocide Research, 1, 13-23.

Singer, J.D. and M. Small (1994). Correlates of War Project: International and Civil War Data, 1816-1993, Ann Arbor, MI: ICPSR.

Smith, Roger (1987). "Human Destructiveness and Politics: The Twentieth Century as an Age of Genocide,” in Isidor Wallimann and Michael Dobrowski (eds.) Genocide and the Modern Age: Etiology and Case Studies of Mass Death, New York: Greenwood Press.

Summers, Craig and Eric Markusen (1998). Collective Violence: Harmful Behavior in Groups and Governments, Lanham MD: Rowman \& Littlefield. 
Stewart, F, V. Fitzgerald, and associates, eds., 2001. War and Underdevelopment, vols. 1 and 2. Oxford, U.K.: Oxford University Press.

Totten, Samuel, William S. Parsons, and Israel Charny (eds.) (1997). Century of Genocide: Eyewitness Accounts and Critical Views, New York: Garland.

U.S. Department of State (2000). 1999 Colombia Country Report on Human Rights Practices.

U.S. Department of State (1999). "Background Notes: Bosnia".

U.S. Department of State (2001). "Background Notes: Sudan".

U.S. Department of State, Bureau of Near Eastern Affairs (2000). Jordan Background Notes.

U.S. Department of State, Bureau of Western Hemisphere Affairs (2001). Guatemala Background Notes.

Worden, Robert and Savada, Andrea Matles (ed.) (1989). Mongolia: a Country Study, Library of Congress.

World Bank, 2003, Breaking the Conflict Trap: Civil War and Development Policy, World Bank: Washington DC, p. 168 


\section{APPENDIX I}

\section{Data Description}

DEMOCRACY Democracy index, ranging from 1 to 10 (measures the general openness of political institutions). The scale is constructed additively, using the following variables: PARCOMP (Competitiveness of participation: extent to which non-elites are able to access institutional structures for political expression); XRCOMP (Executive recruitment competition: extent to which executives are chosen through competitive elections); XROPEN (Executive recruitment openness: opportunity for non-elites to attain executive office); XCONST (Executive constraints: operational independence of chief executive). Whenever a modern polity originated from the merging of two or more old polities, the simple average of the constituting parts was used until the date of the union. Whenever an old polity broke up into two or more modern entities, the values for the bigger state were used until the date of the division. Source: Polity Project, University of Maryland, College Park; years 1800-1998.

DEMO10

DEMO_QUART

DEMO_HIGH

LGDPPC

LGDPPC_QUART

Ding for quartiles of LGDPPC. First quartile. LGDPPC less than 6.81; second quartile: LGDPPC between 6.81 and 7.42; third quartile: LGDPPC between 7.42 and 8.19; fourth quartile: LGDPPC bigger than 8.19

LPOP

XX CENTURY Dummy for the $20^{\text {th }}$ century.
Log of population. Source: Global Development Finance \& World Development Indicators, World Bank, years 1960-1998, and Maddison (1995), years 1820-1959. 
EF

CWAR_D

CIIWAR_D
Ethnic fractionalization index. Measures probability that two randomly selected people from a given country will not belong to the same ethnolinguistic group. Source: Alesina et. al. (2003).

Dummy for civil war. Source: Singer and Small (1994).

Dummy for international, imperial or colonial war. International (interstate) wars are those fought among members of the interstate system. Imperial wars, involve an adversary that is an independent political entity but does not qualify as a member of the interstate system. Colonial wars include international wars in which an adversary was a colony, dependency or protectorate. Source: Singer and Small (1994). 


\section{APPENDIX 2}

\section{List of mass killing episodes}

\begin{tabular}{|c|c|c|c|}
\hline COUNTRY & YEAR & VICTIMS & SOURCE \\
\hline Afghanistan & 1880-1901 & $\begin{array}{l}\text { 2,000-?: killings during unification by Abdur } \\
\text { Rahman }\end{array}$ & Rummel (1997) \\
\hline Afghanistan & 1978-92 & $\begin{array}{l}1.5 \text { to } 2 \text { million: mass murder of supporters } \\
\text { of old regime and rural supporters of rebels } \\
\text { (many ethnic Pushtuns) by Afghan } \\
\text { Communist puppet regime and then more } \\
\text { systematically by Soviet forces }\end{array}$ & $\begin{array}{l}\text { Fein (1992); } \\
\text { Charny (1999) }\end{array}$ \\
\hline Algeria & 1945 & 103: attack on European settlers after WW II & Kuper (1981) \\
\hline Algeria & 1955 & $\begin{array}{l}50 \text { families: attack on European settlers } \\
\text { during revolution }\end{array}$ & Kuper (1981) \\
\hline Algeria & 1962 & $\begin{array}{l}\text { 12,000-150,000: mass murder of Harkis } \\
\text { (French-Muslim troops) \& OAS supporters }\end{array}$ & $\begin{array}{l}\text { Fein (1992); } \\
\text { Rummel } \\
\text { (1997); } \\
\text { Le Monde } \\
\text { (2001) }\end{array}$ \\
\hline Algeria & 1992-98 & $\begin{array}{l}\text { 70,000: killing of civilians by Islamic } \\
\text { fundamentalists }\end{array}$ & Charny (1999) \\
\hline Angola & $1961-62$ & $\begin{array}{l}\text { 400: murder of Europeans during nationalist } \\
\text { uprising }\end{array}$ & Collelo (1989) \\
\hline Angola & 1980-90 & Massacre of indigenous group: San & Charny (1999) \\
\hline Argentina & 1879-81 & $\begin{array}{l}\text { 1,500: indigenous peoples massacred in } \\
\text { Patagonia }\end{array}$ & Rummel (1997) \\
\hline Argentina & 1976-80 & 9,000-30,000: mass murder of leftists & Fein (1992) \\
\hline Australia & 1824-1908 & 10,000: removal/killings of the Aborigines & $\begin{array}{l}\text { Bell-Fialkoff } \\
\text { (1996); Charny } \\
\text { (1999) }\end{array}$ \\
\hline Azerbaijan & 1988 & Massacre/eviction of Armenians & $\begin{array}{l}\text { Bell-Fialkoff } \\
\text { (1996) }\end{array}$ \\
\hline Azerbaijan & 1990 & Massacre of Armenians & $\begin{array}{l}\text { Bell-Fialkoff } \\
\text { (1996) }\end{array}$ \\
\hline Bangladesh & 1979-99 & p: Tribals & Charny (1999) \\
\hline Bosnia & 1992-1995 & $\begin{array}{l}\text { Massacre of Bosnian Muslims by Bosnian } \\
\text { Serbs }\end{array}$ & $\begin{array}{l}\text { Charny (1999); } \\
\text { Bell-Fialkoff } \\
\text { (1996) }\end{array}$ \\
\hline Brazil & 1886-97 & Massacre of the Canudos colony in Bahia. & $\begin{array}{l}\text { Jonassohn and } \\
\text { Bjornson } \\
\text { (1995) }\end{array}$ \\
\hline Brazil & 1986-87 & ip: Nambiquara & Charny (1999) \\
\hline Brazil & 1988 & Massacre of indigenous group: Ticuna & Charny (1999) \\
\hline Brazil & 1988-89, 93 & Massacre of indigenous group: Yanomami & Charny (1999) \\
\hline
\end{tabular}




\begin{tabular}{|c|c|c|c|}
\hline COUNTRY & YEAR & VICTIMS & SOURCE \\
\hline Brazil & 1992 & Massacre of indigenous group: Arara & Charny (1999) \\
\hline Burundi & 1965-73 & $\begin{array}{l}\text { 103,000-303,000: mass murder of Hutu } \\
\text { leaders \& peasants }\end{array}$ & $\begin{array}{l}\text { Fein (1992); } \\
\text { Charny (1999) }\end{array}$ \\
\hline Burundi & $\begin{array}{l}1969,72 \\
88,92,93 \\
95\end{array}$ & Massacres during Hutu-Tutsi conflicts & $\begin{array}{l}\text { Bell-Fialkoff } \\
\text { (1996) }\end{array}$ \\
\hline Burundi & 1993 & $\begin{array}{l}\text { 60,000: massacres during Hutu-Tutsi } \\
\text { conflicts }\end{array}$ & Charny (1999) \\
\hline Cambodia & 1975-79 & $\begin{array}{l}1.5 \text { million: massacre of ethnic Vietnamese, } \\
\text { intellectuals, middle-class people }\end{array}$ & $\begin{array}{l}\text { Andreopoulos } \\
\text { (1994) }\end{array}$ \\
\hline Cambodia & 1975-79 & Massacre of indigenous group: Cham & Charny (1999) \\
\hline Canada & $1500 s-1900$ & Massacre of indigenous peoples & Charny (1999) \\
\hline $\begin{array}{l}\text { Central African } \\
\text { Republic }\end{array}$ & $1978-79$ & $\begin{array}{l}\text { Brutality under the Bokassa regime against } \\
\text { dissidents }\end{array}$ & $\begin{array}{l}\text { Kuper (1981); } \\
\text { Charny (1999) }\end{array}$ \\
\hline Chile & 1973-76 & 2,000-30,000: mass murder of leftists & Fein (1992) \\
\hline Chile & 1976-83 & $\begin{array}{l}\text { 79: kidnapping and "disappearance" of } \\
\text { leftists under the Pinochet rule }\end{array}$ & Charny (1999) \\
\hline Chile & 1986 & Massacre of indigenous group: Mapuche & Charny (1999) \\
\hline China & $1850-1864$ & $\begin{array}{l}\text { 12,000,000: mass killings during Taiping } \\
\text { Rebellion }\end{array}$ & Rummel (1997) \\
\hline China & $1855-1873$ & $\begin{array}{l}\text { 600,000: mass killings during Moslem } \\
\text { Rebellion }\end{array}$ & Rummel (1997) \\
\hline China & $1860 \mathrm{~s}$ & $\begin{array}{l}\text { 3,000,000: mass killings during Triad } \\
\text { Rebellion }\end{array}$ & Rummel (1997) \\
\hline China & 1920s-1949 & $\begin{array}{l}10 \text { million: killing by nationalists before their } \\
\text { final defeat on the mainland }\end{array}$ & Charny (1999) \\
\hline China & 1920s-1949 & $\begin{array}{l}3.5 \text { million: killing by Communists before } \\
\text { their final victory on the mainland }\end{array}$ & Charny (1999) \\
\hline China & $1949-56$ & $\begin{array}{l}\text { 4,500,000 (until 1953): mass murder of } \\
\text { landlords \& rich peasants during land reform; } \\
\text { mass murder of Kuomintang cadre }\end{array}$ & $\begin{array}{l}\text { Charny (1999); } \\
\text { Bell-Fialkoff } \\
\text { (1996); } \\
\text { Fein (1992) }\end{array}$ \\
\hline China & 1959-1979 & 1,200,000: Chinese occupation of Tibet & $\begin{array}{l}\text { Freedom House } \\
\text { (2001) }\end{array}$ \\
\hline China & 1966-75 & $\begin{array}{l}\text { 400,000-850,000: Cultural Revolution } \\
\text { victims }\end{array}$ & Fein (1992) \\
\hline Colombia & 1879 & 40,000 & Rummel (1997) \\
\hline Colombia & 1948-58 & $\begin{array}{l}\text { 180,000: "La Violencia" massacres by } \\
\text { Liberal/Conservative governments }\end{array}$ & Charny (1999) \\
\hline Colombia & $1967-71$ & Mass killings of indigenous group: Cuiva & (1999) \\
\hline Colombia & 1991 & $\begin{array}{l}\text { Mass killings of indigenous groups: Nunak, } \\
\text { Paez }\end{array}$ & Charny (1999) \\
\hline
\end{tabular}




\begin{tabular}{|c|c|c|c|}
\hline COUNTRY & YEAR & VICTIMS & SOURCE \\
\hline Colombia & $1999-2000$ & $\begin{array}{l}\text { 1,000-?: killing by right-wing paramilitary } \\
\text { groups of alleged sympathizers of left-wing } \\
\text { guerrillas }\end{array}$ & $\begin{array}{l}\text { US State Dept } \\
\text { (2000); } \\
\text { Amnesty Int'l } \\
\text { (1999) }\end{array}$ \\
\hline $\begin{array}{l}\text { Congo, Dem. } \\
\text { Rep. }\end{array}$ & 1977-? & $\begin{array}{l}\text { 3,000-4,000: mass murder of tribal opponents } \\
\text { \& political opponents of Mobutu }\end{array}$ & Fein (1992) \\
\hline Croatia & $1941-45$ & $\begin{array}{l}\text { 500,000-655,000: massacre of Serbs, Jews, } \\
\text { and Gypsies during WW II }\end{array}$ & Charny (1999) \\
\hline Croatia & 1993-95 & $\begin{array}{l}\text { Cleansing of Muslim and Serbian civilians } \\
\text { from Bosnia during Bosnia war }\end{array}$ & Charny (1999) \\
\hline Cyprus & $1955-1974$ & Greek-Turkey conflict over the territory & $\begin{array}{l}\text { Bell-Fialkoff } \\
\text { (1996) }\end{array}$ \\
\hline $\begin{array}{l}\text { Dominican } \\
\text { Republic }\end{array}$ & 1937 & $\begin{array}{l}\text { 15,000-20,000: massacre of Haitians and } \\
\text { black Spanish-speakers }\end{array}$ & $\begin{array}{l}\text { Bell-Fialkoff } \\
\text { (1996) }\end{array}$ \\
\hline El Salvador & 1932 & $\begin{array}{l}\text { 30,000: "La Matanza": Government } \\
\text { repression of Indians (Pipil) and peasants }\end{array}$ & $\begin{array}{l}\text { Haggarty } \\
\text { (1988) }\end{array}$ \\
\hline El Salvador & 1980-1992 & 20,000-70,000: mass murder of leftists & Fein (1992) \\
\hline $\begin{array}{l}\text { Equatorial } \\
\text { Guinea }\end{array}$ & 1969-79 & $\begin{array}{l}\text { 1,000-50,000: mass murder of Bubi tribe \& } \\
\text { political opponents of Macias }\end{array}$ & Fein (1992) \\
\hline Ethiopia & 1974-79 & 30,000: mass murder of political opposition & Fein (1992) \\
\hline Ethiopia & 1984-85 & Victims of forced resettlement & $\begin{array}{l}\text { Fein (1992); } \\
\text { Charny (1999) }\end{array}$ \\
\hline France & 1830 & $\begin{array}{l}\text { 1,800: demonstrators shot during Paris } \\
\text { Uprising }\end{array}$ & Rummel (1997) \\
\hline France & 1871 & 15,000: executions during Paris Commune & Rummel (1997) \\
\hline France & 1945 & $\begin{array}{l}1,500 \text { to } 50,000 \text { Muslims: reprisals from } \\
\text { colonial authorities after attack on European } \\
\text { settlers in Algeria }\end{array}$ & Kuper (1981) \\
\hline France & $1947-48$ & $\begin{array}{l}\text { 10,000-80,000: mass murder of Malagasy } \\
\text { nationalists }\end{array}$ & Fein (1992) \\
\hline France & 1955 & $\begin{array}{l}12,000 \text { Muslims: reprisals from colonial } \\
\text { authorities after attack on European settlers } \\
\text { in Algeria }\end{array}$ & Kuper (1981) \\
\hline Germany & 1900-18 & $\begin{array}{l}\text { 132,000: colonial massacres } \\
\text { (among these: } 65,000 \text { during killings of } \\
\text { Herero in German SW Africa between 1904- } \\
\text { 07) }\end{array}$ & $\begin{array}{l}\text { Charny (1999); } \\
\text { Rubenstein, } \\
\text { Dobkowski and } \\
\text { Wallimann } \\
\text { (2000) }\end{array}$ \\
\hline Germany & 1933-1945 & $\begin{array}{l}6 \text { million Jewish people; } 3 \text { million Poles; } \\
219,700 \text { to } 1.5 \text { million Roma; } 70,000 \\
\text { disables; } 5,000 \text { to } 15,000 \text { homosexuals; } \\
\text { cleansing of communists and Jehovah's } \\
\text { Witnesses }\end{array}$ & $\begin{array}{l}\text { Bell-Fialkoff } \\
\text { (1996) }\end{array}$ \\
\hline
\end{tabular}




\begin{tabular}{|c|c|c|c|}
\hline COUNTRY & YEAR & VICTIMS & SOURCE \\
\hline Guatemala & 1960-96 & $\begin{array}{l}\text { 200,000: mass murder of indigenous group } \\
\text { (Maya) \& Leftists }\end{array}$ & $\begin{array}{l}\text { Charny (1999); } \\
\text { Fein (1992); } \\
\text { US State Dept } \\
\text { (2001) }\end{array}$ \\
\hline Haiti & 1804 & Massacre of the French colonists & $\begin{array}{l}\text { Bell-Fialkoff } \\
\text { (1996) }\end{array}$ \\
\hline Hungary & 1919 & 590: "Red Terror" & Burant (1989) \\
\hline Hungary & 1919 & 5,000: "White Terror" & Burant (1989) \\
\hline Hungary & 1941 & Massacre of Yugoslav citizens, mostly Serbs & $\begin{array}{l}\text { Bell-Fialkoff } \\
\text { (1996) }\end{array}$ \\
\hline India & $1946-47$ & $\begin{array}{l}\text { 500,000: massacre and post-war flight of } \\
\text { Muslims }\end{array}$ & $\begin{array}{l}\text { Bell-Fialkoff } \\
\text { (1996) }\end{array}$ \\
\hline India & 1968-82 & 1,000-3,000: mass murder of Naxalites & Fein (1992) \\
\hline India & 1984 & $\begin{array}{l}\text { 5,000-10,000: killing of Sikhs during anti- } \\
\text { Sikh violence }\end{array}$ & Charny (1999) \\
\hline India & $1992-93$ & $\begin{array}{l}\text { Riots between Muslims and Hindus, violence } \\
\text { mostly suffered by Muslims }\end{array}$ & $\begin{array}{l}\text { Human Rights } \\
\text { Watch (1995) }\end{array}$ \\
\hline Indonesia & $1965-67$ & $\begin{array}{l}\text { 500,000-1,000,000: anti-Communist, anti- } \\
\text { Chinese massacre }\end{array}$ & Fein (1992) \\
\hline Indonesia & 1976-87 & $\begin{array}{l}\text { East Timor massacres by Indonesian army } \\
(68,000-230,000 \text { killed between 1976-79) }\end{array}$ & $\begin{array}{l}\text { Andreopoulos } \\
\text { (1994); } \\
\text { Charny (1999) }\end{array}$ \\
\hline Indonesia & 1989 & Killings of indigenous group: Auyu & Charny (1999) \\
\hline $\begin{array}{l}\text { Iran, Islamic } \\
\text { Rep. }\end{array}$ & $\begin{array}{l}\text { 1840s- } \\
1850 s\end{array}$ & 20,000 : Baha' is put to death & Rummel (1997) \\
\hline $\begin{array}{l}\text { Iran, Islamic } \\
\text { Rep. }\end{array}$ & 1979-84 & $\begin{array}{l}\text { 210: campaign of persecution against the } \\
\text { Baha'i community }\end{array}$ & Fein (1992) \\
\hline $\begin{array}{l}\text { Iran, Islamic } \\
\text { Rep. }\end{array}$ & 1981-? & $\begin{array}{l}\text { 10,000-20,000: mass murder of Kurds, } \\
\text { Baha'is, \& Mujahedeen }\end{array}$ & Fein (1992) \\
\hline Iraq & $1959-75$ & Mass murder of Kurdish nationalists & Fein (1992) \\
\hline Iraq & 1988 & 5,000: Iraqi Kurds victims & $\begin{array}{l}\text { Andreopoulos } \\
\text { (1994) }\end{array}$ \\
\hline Iraq & 1991 & Cleansing of Kurds during Persian Gulf War & $\begin{array}{l}\text { Bell-Fialkoff } \\
\text { (1996); } \\
\text { Cordesman } \\
\text { (1994) }\end{array}$ \\
\hline Israel & 1948 & $\begin{array}{l}\text { 254: Palestinians killed in Deir Yassin by } \\
\text { Irgun and Stern gang }\end{array}$ & $\begin{array}{l}\text { Bickerton and } \\
\text { Klausner } \\
\text { (1998) }\end{array}$ \\
\hline Israel & 1982 & $\begin{array}{l}\text { 700-800: Sabra \& Shatila massacre of } \\
\text { refugees (mostly Palestinians) by Christian } \\
\text { Phalangists in an area under Israeli control }\end{array}$ & $\begin{array}{l}\text { Bickerton and } \\
\text { Klausner } \\
\text { (1998); Kahan, } \\
\text { Barak and Efrat } \\
\text { (1983) }\end{array}$ \\
\hline
\end{tabular}




\begin{tabular}{|c|c|c|c|}
\hline COUNTRY & YEAR & VICTIMS & SOURCE \\
\hline Israel & 1987-1993 & $\begin{array}{l}\text { 1,095 (800 until 1990): Palestinians killed by } \\
\text { Israeli security forces during Intifada }\end{array}$ & $\begin{array}{l}\text { Bickerton and } \\
\text { Klausner } \\
\text { (1998); } \\
\text { Bloomberg } \\
\text { (1993) }\end{array}$ \\
\hline Italy & 1937 & $\begin{array}{l}\text { 30,000: Mass executions of Ethiopians by } \\
\text { Italians, after failed assassination attempt } \\
\text { against Graziani }\end{array}$ & $\begin{array}{l}\text { Ofcansky and } \\
\text { Berry (1991) }\end{array}$ \\
\hline Japan & 1935-39 & $\begin{array}{l}4 \text { to } 6.3 \text { million: massacre of Chinese, } \\
\text { including Rape of Nanking ( } 200,000 \text { victims) }\end{array}$ & Charny (1999) \\
\hline Japan & 1935-39 & $\begin{array}{l}\text { 20,000: massacre of Indonesian civilians by } \\
\text { Japanese troops during WW II }\end{array}$ & Charny (1999) \\
\hline Jordan & $\begin{array}{l}\text { 1920-21, } \\
1929,1946\end{array}$ & Massacre of Jewish refugees & $\begin{array}{l}\text { Bell-Fialkoff } \\
\text { (1996) }\end{array}$ \\
\hline Kenya & 1991-94 & 1,500: violence in tribal clashes & $\begin{array}{l}\text { Human Rights } \\
\text { Watch (1995) }\end{array}$ \\
\hline Lao PDR & 1963-? & $\begin{array}{l}\text { 18,000-20,000: mass murder of Meo } \\
\text { tribesmen }\end{array}$ & Fein (1992) \\
\hline Lao PDR & 1979-86 & Mass killings of indigenous group: H'mong & Charny (1999) \\
\hline Lebanon & 1975-90 & $\begin{array}{l}\text { 200,000: deaths during civil war caused by } \\
\text { religious hatred }\end{array}$ & $\begin{array}{l}\text { Human Rights } \\
\text { Watch (1995) }\end{array}$ \\
\hline Liberia & 1990 & $\begin{array}{l}\text { 600: massacre of refugees in a church by } \\
\text { government troops }\end{array}$ & Charny (1999) \\
\hline Mali & 1988-90 & Massacre of indigenous group: Tuareg & Charny (1999) \\
\hline Mongolia & 1929-32 & $\begin{array}{l}\text { Killings among monastic class, nobility and } \\
\text { political opposition; collectivization and } \\
\text { Party purges by Communists }\end{array}$ & $\begin{array}{l}\text { Worden and } \\
\text { Savada(1989) }\end{array}$ \\
\hline Myanmar & 1978 & Mass murder of Muslims in border region & Fein (1992) \\
\hline Myanmar & 1988 & $\begin{array}{l}\text { 3,000: army opening fire on peaceful pro- } \\
\text { democracy demonstrations }\end{array}$ & $\begin{array}{l}\text { Freedom House } \\
\text { (2001) }\end{array}$ \\
\hline Netherlands & $1873-1913$ & $\begin{array}{l}\text { 30,000-100,000: massacre during occupation } \\
\text { of Sumatra }\end{array}$ & Rummel (1997) \\
\hline Nicaragua & 1981-86 & Massacre of indigenous group: Miskito & Charny (1999) \\
\hline Niger & 1988-90 & Massacre of indigenous group: Tuareg & Charny (1999) \\
\hline Nigeria & 1966-70 & $\begin{array}{l}1 \text { million: massacre, expulsion and starvation } \\
\text { of Igbos }\end{array}$ & $\begin{array}{l}\text { Bell-Fialkoff } \\
\text { (1996); } \\
\text { Rosenbaum } \\
\text { (1997) }\end{array}$ \\
\hline Pakistan & 1946-47 & Massacre and flight of indigenous peoples & $\begin{array}{l}\text { Bell-Fialkoff } \\
\text { (1996) }\end{array}$ \\
\hline Pakistan & 1958-74 & Mass murder of Baluchi tribesmen & Fein (1992) \\
\hline
\end{tabular}




\begin{tabular}{|c|c|c|c|}
\hline COUNTRY & YEAR & VICTIMS & SOURCE \\
\hline Pakistan & 1971 & $\begin{array}{l}\text { 1,250,000-3,000,000: mass murder of } \\
\text { Bengali nationalists }\end{array}$ & $\begin{array}{l}\text { Fein (1992); } \\
\text { Charny (1999); } \\
\text { Rummel (1997) }\end{array}$ \\
\hline $\begin{array}{l}\text { Papua New } \\
\text { Guinea }\end{array}$ & 1988 & Massacre of indigenous group: Dani & Charny (1999) \\
\hline $\begin{array}{l}\text { Papua New } \\
\text { Guinea }\end{array}$ & $1990-91$ & Massacre of indigenous group: Nasioi & Charny (1999) \\
\hline Paraguay & $1962-76$ & $\begin{array}{l}\text { 900: mass murder of indigenous people } \\
\text { (Ache) }\end{array}$ & $\begin{array}{l}\text { Fein (1992); } \\
\text { Charny (1999) }\end{array}$ \\
\hline Paraguay & 1990-91 & Massacre of indigenous group: Pai Tavytere & Charny (1999) \\
\hline Philippines & $1968-85$ & $\begin{array}{l}\text { 10,000-100,000: mass murder of Moro } \\
\text { (Muslim) nationalists }\end{array}$ & Fein (1992) \\
\hline Philippines & 1987 & Massacre of indigenous group: Atta & Charny (1999) \\
\hline Poland & $1945-48$ & 1,583,000: removal of Germans & $\begin{array}{l}\text { Bell-Fialkoff } \\
\text { (1996); Charny } \\
\text { (1999) }\end{array}$ \\
\hline Portugal & $1961-62$ & $\begin{array}{l}\text { 40,000: mass murder of Bakongo during } \\
\text { suppression of nationalist uprising in Angola }\end{array}$ & $\begin{array}{l}\text { Fein (1992); } \\
\text { Collelo (1989) }\end{array}$ \\
\hline Romania & 1907 & $\begin{array}{l}\text { 10,000: Government suppression of peasant } \\
\text { revolt }\end{array}$ & $\begin{array}{l}\text { Bachman } \\
\text { (1989) }\end{array}$ \\
\hline Romania & $\begin{array}{l}1919,36 \\
40,49,56 \\
59,90\end{array}$ & $\begin{array}{l}\text { Romanian-Hungarian conflict in } \\
\text { Transylvania (under Romanian control) }\end{array}$ & $\begin{array}{l}\text { Bell-Fialkoff } \\
\text { (1996) }\end{array}$ \\
\hline Romania & 1989-93 & $\begin{array}{l}\text { 10: killing of Romas and burning of Roma } \\
\text { homes by ethnic Romanians and ethnic } \\
\text { Hungarians without government sanction }\end{array}$ & $\begin{array}{l}\text { Human Rights } \\
\text { Watch (1995) }\end{array}$ \\
\hline $\begin{array}{l}\text { Russian } \\
\text { Federation, } \\
\text { former USSR }\end{array}$ & 1881 & 5,000: Turkmens slaughtered & Rummel (1997) \\
\hline $\begin{array}{l}\text { Russian } \\
\text { Federation, } \\
\text { former USSR }\end{array}$ & 1881-1882 & $\begin{array}{l}\text { 50-"a few hundred": Jews killed during wave } \\
\text { of pogroms }\end{array}$ & $\begin{array}{l}\text { Klier and } \\
\text { Lambroza } \\
\text { (1992) }\end{array}$ \\
\hline $\begin{array}{l}\text { Russian } \\
\text { Federation, } \\
\text { former USSR }\end{array}$ & 1903-1906 & 3,188: Jews killed during wave of pogroms & $\begin{array}{l}\text { Edelheit and } \\
\text { Edelheit (1994) }\end{array}$ \\
\hline $\begin{array}{l}\text { Russian } \\
\text { Federation, } \\
\text { former USSR }\end{array}$ & 1919 & $\begin{array}{l}\text { 700,000: mass killing of the Cossacks during } \\
\text { suppression of the Don Cossack revolt }\end{array}$ & Charny (1999) \\
\hline $\begin{array}{l}\text { Russian } \\
\text { Federation, } \\
\text { former USSR }\end{array}$ & 1922-1941 & $\begin{array}{l}\text { Cleansing of the bourgeoisie, aristocracy, the } \\
\text { kulaks }\end{array}$ & $\begin{array}{l}\text { Bell-Fialkoff } \\
\text { (1996) }\end{array}$ \\
\hline
\end{tabular}




\begin{tabular}{|c|c|c|c|}
\hline COUNTRY & YEAR & VICTIMS & SOURCE \\
\hline $\begin{array}{l}\text { Russian } \\
\text { Federation, } \\
\text { former USSR }\end{array}$ & $1930-37$ & 6,500,000: cleansing of kulaks & $\begin{array}{l}\text { Chalk and } \\
\text { Jonassohn } \\
\text { (1990); } \\
\text { Charny (1999) }\end{array}$ \\
\hline $\begin{array}{l}\text { Russian } \\
\text { Federation, } \\
\text { former USSR }\end{array}$ & 1932-33 & $\begin{array}{l}5 \text { to } 7 \text { million: artificially induced famine of } \\
\text { peasants, mostly Ukrainians }\end{array}$ & $\begin{array}{l}\text { Chalk and } \\
\text { Jonassohn } \\
\text { (1990); } \\
\text { Charny (1999) }\end{array}$ \\
\hline $\begin{array}{l}\text { Russian } \\
\text { Federation, } \\
\text { former USSR }\end{array}$ & $1937-38$ & $\begin{array}{l}\text { 1,000,000: execution of Communist Party } \\
\text { members during the Great Terror }\end{array}$ & Charny (1999) \\
\hline $\begin{array}{l}\text { Russian } \\
\text { Federation, } \\
\text { former USSR }\end{array}$ & $1940-53$ & $\begin{array}{l}\text { Anti-nationalist deportation of the Balts in } \\
\text { Estonia }\end{array}$ & $\begin{array}{l}\text { Bell-Fialkoff } \\
\text { (1996) }\end{array}$ \\
\hline $\begin{array}{l}\text { Russian } \\
\text { Federation, } \\
\text { former USSR }\end{array}$ & $1943-47$ & $\begin{array}{l}500,000-1,100,000 \text { : mass murder of } \\
\text { repatriated Soviet nationals }\end{array}$ & Fein (1992) \\
\hline $\begin{array}{l}\text { Russian } \\
\text { Federation, } \\
\text { former USSR }\end{array}$ & 1943-57 & $\begin{array}{l}\text { 230,000: mass murder of Chechens, Ingushi, } \\
\text { Karachai \& Balkars }\end{array}$ & Fein (1992) \\
\hline $\begin{array}{l}\text { Russian } \\
\text { Federation, } \\
\text { former USSR }\end{array}$ & $1944-68$ & $\begin{array}{l}\text { 57,000-175,000: mass murder of } \\
\text { Meskhetians \& Crimean Tatars }\end{array}$ & Fein (1992) \\
\hline $\begin{array}{l}\text { Russian } \\
\text { Federation, } \\
\text { former USSR }\end{array}$ & $1945-53$ & Cleansing of Jews, intelligentsia, etc & $\begin{array}{l}\text { Bell-Fialkoff } \\
\text { (1996) }\end{array}$ \\
\hline $\begin{array}{l}\text { Russian } \\
\text { Federation, } \\
\text { former USSR }\end{array}$ & 1947-? & Mass murder of Ukrainian nationalists & Fein (1992) \\
\hline $\begin{array}{l}\text { Russian } \\
\text { Federation, } \\
\text { former USSR }\end{array}$ & 1949 & 50,000 to 60,000: deportation of Estonians & Charny (1999) \\
\hline Rwanda & 1959-94 & Massacres during Hutu-Tutsi conflicts & $\begin{array}{l}\text { Bell-Fialkoff } \\
\text { (1996) }\end{array}$ \\
\hline Rwanda & $1962-64$ & $\begin{array}{l}\text { 6,000-16,000: mass murder of Tutsi ruling } \\
\text { class }\end{array}$ & $\begin{array}{l}\text { Fein (1992); } \\
\text { Kuper (1981) }\end{array}$ \\
\hline Rwanda & 1994 & $\begin{array}{l}\text { 850,000-860,000: massacres during Hutu- } \\
\text { Tutsi conflicts }\end{array}$ & Charny (1999) \\
\hline Rwanda & 1996-97 & $\begin{array}{l}\text { 50,000-100,000: killings of Hutu refugees } \\
\text { from Rwanda and Burundi in Congo by Tutsi } \\
\text { army from Rwanda }\end{array}$ & Charny (1999) \\
\hline Somalia & 1988-89 & Mass murder of Issak clan (Northerners) & Fein (1992) \\
\hline South Africa & $1980-90$ & $\begin{array}{l}\text { Massacre of indigenous group in occupied } \\
\text { Namibia: San }\end{array}$ & Charny (1999) \\
\hline
\end{tabular}




\begin{tabular}{|c|c|c|c|}
\hline COUNTRY & YEAR & VICTIMS & SOURCE \\
\hline South Africa & 1990-94 & $\begin{array}{l}\text { 14,000: political violence during the } \\
\text { transition period before the first all-race } \\
\text { election }\end{array}$ & $\begin{array}{l}\text { Human Rights } \\
\text { Watch (1995) }\end{array}$ \\
\hline Spain & 1936-39 & $\begin{array}{l}\text { 430,000: killing of soldiers and civilians by } \\
\text { Loyalists and Fascists during Spanish Civil } \\
\text { War and more killing of Loyalists by Fascists } \\
\text { after war }\end{array}$ & Charny (1999) \\
\hline Sri Lanka & $\begin{array}{l}1958,71 \\
77,81,83- \\
86,95\end{array}$ & 40,000: Tamil-Sinhalese conflict & $\begin{array}{l}\text { Bell-Fialkoff } \\
\text { (1996) }\end{array}$ \\
\hline Sudan & $1952-72$ & $\begin{array}{l}\text { 500,000: mass murder of southern } \\
\text { nationalists }\end{array}$ & $\begin{array}{l}\text { Kuper (1981); } \\
\text { Metz (1991); } \\
\text { Fein (1992); } \\
\text { Rubenstein, } \\
\text { Dobkowski and } \\
\text { Wallimann } \\
(2000)\end{array}$ \\
\hline Sudan & 1991-92 & Mass killing & Charny (1999) \\
\hline Sudan & 1992-93 & $\begin{array}{l}\text { Mass killing of indigenous group: Kinka, } \\
\text { Nuer }\end{array}$ & Charny (1999) \\
\hline Sudan & 1983-99 & 1.5 million: total civil war deaths & $\begin{array}{l}\text { Freedom House } \\
\text { (2001); } \\
\text { Kebbede } \\
\text { (1999); } \\
\text { US State Dept } \\
\text { (2001) }\end{array}$ \\
\hline $\begin{array}{l}\text { Syrian Arab } \\
\text { Republic }\end{array}$ & 1981-82 & $\begin{array}{l}\text { 5,000-25,000: mass murder of Muslim } \\
\text { Brotherhood }\end{array}$ & Fein (1992) \\
\hline Taiwan & 1947 & $\begin{array}{l}\text { 10,000-40,000: mass murder of Taiwanese } \\
\text { nationalists }\end{array}$ & Fein (1992) \\
\hline Turkey & $1822-23$ & 68,000: Greeks killed & RuI \\
\hline Turkey & 1826 & 20,000-39,800: Janissaries massacred & Rummel (1997) \\
\hline Turkey & 1850 & 10,000: Mosul Assyrians massacred & Rummel (1997) \\
\hline Turkey & 1850 & 10,000: Kurdistan massacre & Rummel (1997) \\
\hline Turkey & 1860 & $\begin{array}{l}\text { 11,000: Lebanon/Damascus massacre of } \\
\text { Christians }\end{array}$ & $\begin{array}{l}\text { Rummel (1997) } \\
\text { Bell-Fialkoff } \\
\text { (1996) }\end{array}$ \\
\hline Turkey & 1881 & $\begin{array}{l}\text { 2,000: Alexandria massacre of } \\
\text { Armenians/other Christians }\end{array}$ & Rummel (1997) \\
\hline Turkey & 1881 & 4,000: death sentences of Albanians & (1997) \\
\hline Turkey & 1892 & $\begin{array}{l}\text { 3,500: massacre of Turkified Armenians and } \\
\text { foreign soldiers }\end{array}$ & Rummel (1997) \\
\hline
\end{tabular}




\begin{tabular}{|c|c|c|c|}
\hline COUNTRY & YEAR & VICTIMS & SOURCE \\
\hline Turkey & 1909 & $\begin{array}{l}\text { 25,000-30,000: massacres of Armenians in } \\
\text { Adana }\end{array}$ & $\begin{array}{l}\text { Chorbajian and } \\
\text { Shirinian } \\
\text { (1998); Charny } \\
\text { (1999) }\end{array}$ \\
\hline Turkey & 1876-79 & 15,000: killing/massacre of Bulgars & Rummel (1997) \\
\hline Turkey & 1894-96 & $\begin{array}{l}200,000 \text { ( } 8 \% \text { of total Armenian population in } \\
\text { Turkey): massacres of Armenians by Kurds }\end{array}$ & $\begin{array}{l}\text { Bell-Fialkoff } \\
\text { (1996) }\end{array}$ \\
\hline Turkey & 1914-1918 & $\begin{array}{l}\text { Massacres/eviction of Nestorian and Jacobite } \\
\text { Christians and the Maronites of Lebanon }\end{array}$ & $\begin{array}{l}\text { Bell-Fialkoff } \\
\text { (1996) }\end{array}$ \\
\hline Turkey & $1915-1918$ & $\begin{array}{l}\text { Massacres of Armenians (1.5 million in } \\
\text { Armenia; 30,000 in Baku; 32,000 in Shusha) }\end{array}$ & $\begin{array}{l}\text { Bell-Fialkoff } \\
\text { (1996) }\end{array}$ \\
\hline Turkey & $1924-1927$ & As many as 30,000 : anti-Kurdish campaigns & $\begin{array}{l}\text { Bell-Fialkoff } \\
\text { (1996); Metz } \\
\text { (1995) }\end{array}$ \\
\hline Turkey & 1922, 1974 & $\begin{array}{l}\text { 30,000: massacre of Christians (mostly } \\
\text { Greeks), forced population exchange with } \\
\text { Greece }\end{array}$ & $\begin{array}{l}\text { Bell-Fialkoff } \\
(1996)\end{array}$ \\
\hline Turkey & $1937-38$ & $\begin{array}{l}\text { Military campaigns against Dersim tribes of } \\
\text { Kurds }\end{array}$ & $\begin{array}{l}\text { Andreopoulos } \\
\text { (1994) }\end{array}$ \\
\hline Uganda & 1971-79 & $\begin{array}{l}\text { 100,000-500,000: mass murder of } \\
\text { Karamojong, Acholi, Lango, Catholic clergy, } \\
\text { \& political opponents of Idi Amin }\end{array}$ & $\begin{array}{l}\text { Fein (1992); } \\
\text { Bell-Fialkoff } \\
\text { (1996) }\end{array}$ \\
\hline Uganda & 1979-86 & $\begin{array}{l}\text { 50,000-100,000: mass murder of } \\
\text { Karamojong, Nilotic tribes, Bagandans, \& } \\
\text { supporters of Amin regime }\end{array}$ & Fein (1992) \\
\hline USA & $1500 s-1900$ & Massacre of indigenous peoples & Charny (1999) \\
\hline USA & 1830s & $\begin{array}{l}\text { 17: expulsion of Mormon communities from } \\
\text { the state of Missouri }\end{array}$ & $\begin{array}{l}\text { Bell-Fialkoff } \\
\text { (1996) }\end{array}$ \\
\hline USA & $\begin{array}{l}\text { Pre-20th } \\
\text { century }\end{array}$ & $\begin{array}{l}\text { 25,000: total indigenous battle- } \\
\text { dead/massacred/killed }\end{array}$ & Rummel (1997) \\
\hline Vietnam & 1953-54 & $\begin{array}{l}\text { 15,000: mass murder of Catholic landlords \& } \\
\text { rich and middle peasants }\end{array}$ & Fein (1992) \\
\hline Vietnam & 1965-72 & $\begin{array}{l}\text { 475,000: mass murder of civilian in NLF } \\
\text { areas }\end{array}$ & Fein (1992) \\
\hline Vietnam & 1975-87 & $\begin{array}{l}\text { 250,000: mass murder of "Boat people" } \\
\text { (Vietnamese/Chinese) }\end{array}$ & Charny (1999) \\
\hline West Bank and & 1948 & 77: Israeli civilians killed by Arab troops on & Bickerton and \\
\hline Gaza & & $\begin{array}{l}\text { Mount Scopus (in response to Deir Yassin } \\
\text { massacre) }\end{array}$ & $\begin{array}{l}\text { Klausner } \\
\text { (1998) }\end{array}$ \\
\hline $\begin{array}{l}\text { West Bank and } \\
\text { Gaza }\end{array}$ & 1987-1994 & 171: Israelis killed during Intifada & $\begin{array}{l}\text { Bloomberg } \\
\text { (1993) }\end{array}$ \\
\hline Yugoslavia & $1945-48$ & $\begin{array}{l}36,000 \text { to 60,000: crush of Albanian } \\
\text { resistance of Serbian rule in Kosovo }\end{array}$ & $\begin{array}{l}\text { Bell-Fialkoff } \\
\text { (1996) }\end{array}$ \\
\hline
\end{tabular}




\begin{tabular}{|c|c|c|c|}
\hline COUNTRY & YEAR & VICTIMS & SOURCE \\
\hline Yugoslavia & 1991-95 & $\begin{array}{l}\text { 200,000: killing of Muslims and Croats in } \\
\text { Bosnia during Bosnia war. }\end{array}$ & $\begin{array}{l}\text { Charny (1999); } \\
\text { US State Dept } \\
\text { (1999) }\end{array}$ \\
\hline Yugoslavia & 1999 & $\begin{array}{l}\text { 10,000-100,000: cleansing of Albanian } \\
\text { Muslims by Serbians during Kosovo war }\end{array}$ & Charny (1999) \\
\hline Zimbabwe & $1982-83$ & Killings of indigenous group: Tyua & Charny (1999) \\
\hline
\end{tabular}

